\title{
GEOHYDROLOGY OF THE FLINTS POND AQUIFER, HOLLIS, NEW HAMPSHIRE
}

\section{BY JOSEPH D. AYOTIE and TRACY H. DORGAN}

\section{U.S. GEOLOGICAL SURVEY \\ Open-File Report 95-363}

Prepared in cooperation with the

NEW HAMPSHIRE DEPARTMENT OF ENVIRONMENTAL SERVICES,

WATER SUPPLY AND POLLUTION CONTROL DIVISION, BIOLOGY BUREAU

Bow, New Hampshire 1995 


\title{
U.S. DEPARTMENT OF THE INTERIOR
}

\section{BRUCE BABBITT, Secretary}

\author{
U.S. GEOLOGICAL SURVEY \\ Gordon P. Eaton, Director
}

For additional information write to:

District Chlef

U.S. Geological Survey

525 Clinton Street

Bow, NH 03304
Copies of this report may be purchased from:

\author{
U.S. Geological Survey \\ Earth Science Information Center \\ Open-File Reports Section \\ Box 25286, MS 517 \\ Federal Center \\ Denver, CO 80225
}




\section{CONTENTS}

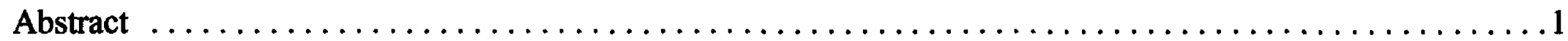

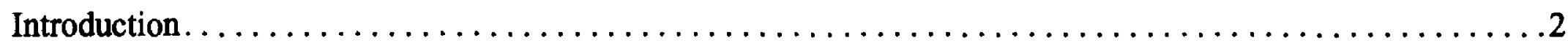

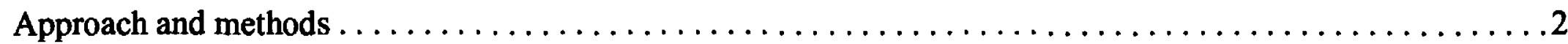

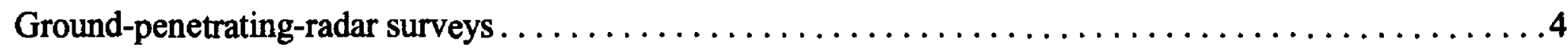

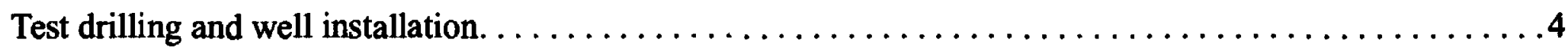

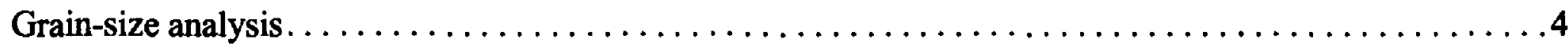

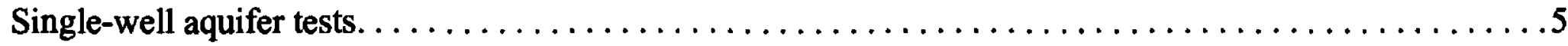

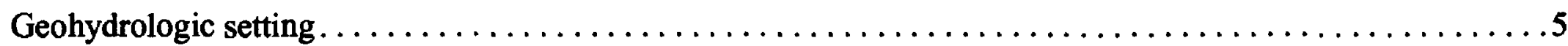

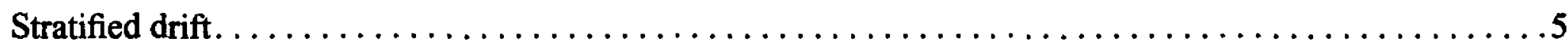

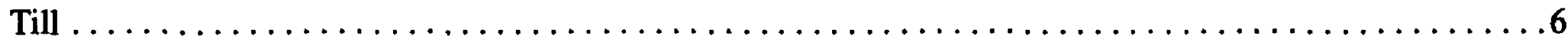

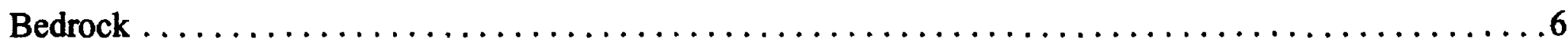

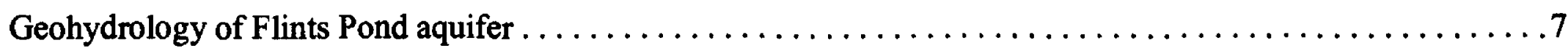

Stratigraphy of geohydrologic units and altitude of water table $\ldots \ldots \ldots \ldots \ldots \ldots \ldots \ldots \ldots \ldots \ldots$

Stratigraphy, as inferred from ground-penetrating-radar data $\ldots \ldots \ldots \ldots \ldots \ldots \ldots \ldots \ldots \ldots$

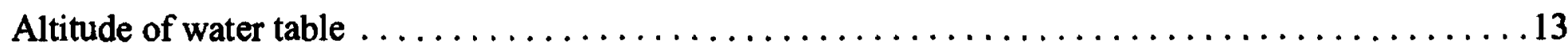

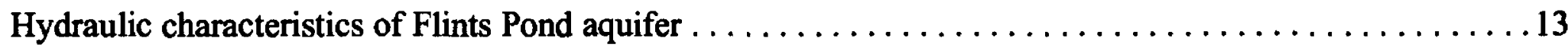

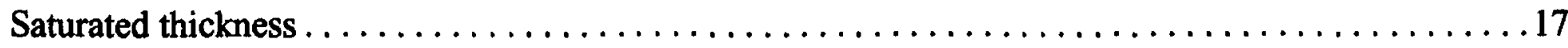

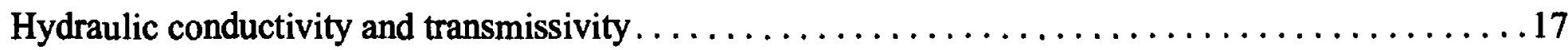

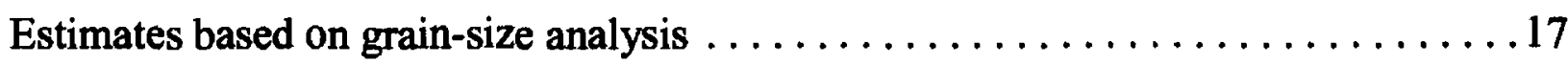

Estimates based on single-well aquifer tests $\ldots \ldots \ldots \ldots \ldots \ldots \ldots \ldots \ldots \ldots$

Relation between hydraulic conductivity and ground-penetrating-radar data $\ldots \ldots \ldots \ldots \ldots \ldots 19$

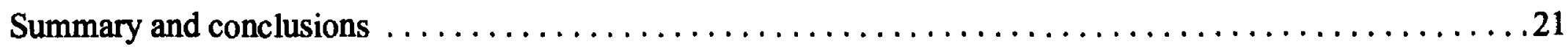

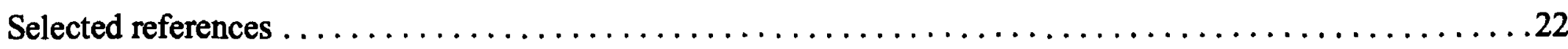

\section{ILLUSTRATIONS}

Figure 1. Map showing location of study area, ground-penetrating-radar profiles, test borings, and observation wells near Flints Pond, Hollis, New Hampshire. . . . . . . . . . 3

2-5. Unprocessed ground-penetrating-radar profile near Flints Pond, Hollis, New Hampshire:

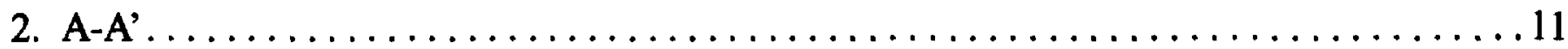




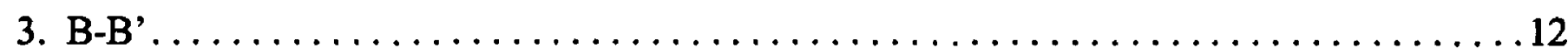

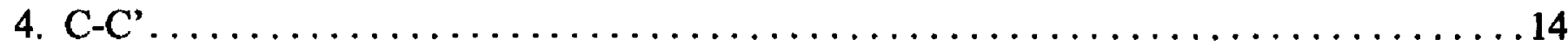

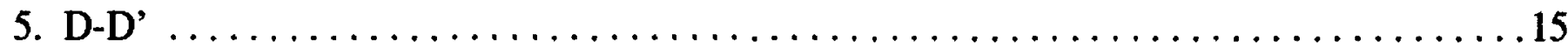

6. Map showing altitude of water table for the Flints Pond aquifer, Hollis, New Hampshire,

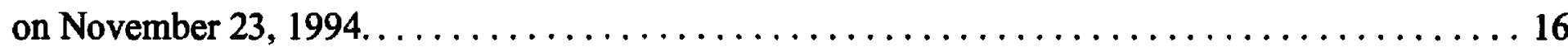

7. Map showing saturated thickness and transmissivity zones, Flints Pond aquifer,

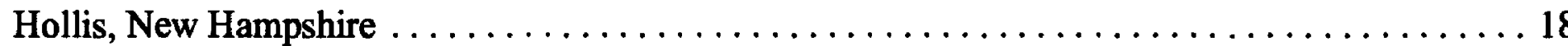

8. Relation between hydraulic conductivity and ground-penetrating-radar reflector signature for part of profile B-B' near northern end of Flints Pond, Hollis, New Hampshire21. 20

\section{TABLES}

Table 1. Relation of mean bulk hydraulic conductivity to median grain size and degree of sorting of

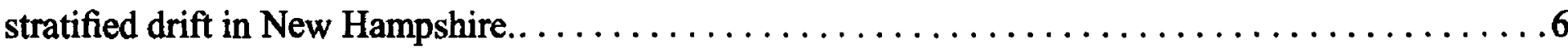

2. Data for selected wells and borings in the Flints Pond aquifer, Hollis, New Hampshire. . . . . . . 8

3. Ground-penetrating-radar propagation velocities for saturated stratified drift near Flints Pond, Hollis, New Hampshire. . . . . . . . . . . . . . . . . . . . . . . . . . 10

4. Summary of estimated hydraulic conductivity from grain-size analyses, well-log descriptions, and single-well aquifer tests for selected wells in the Flints Pond aquifer, Hollis, New Hampshire. . . 19 
CONVERSION FACTORS AND VERTICAL DATUM

\begin{tabular}{lcl} 
Multiply & By & To obtain \\
\hline & & millimeter (mm) \\
inch (in.) & 25.4 & meter \\
foot (ft) & 0.3048 & kilometer \\
mile (mi) & 1.609 & square kilometer \\
square mile ( $\left.\mathrm{mi}^{2}\right)$ & 2.590 & square meter \\
acre & 4,047 & kilometer per hour \\
mile per hour (mi/h) & 1.609 & meter per nanosecond \\
foot per nanosecond (ft/ns) & 0.3048 & meter per day \\
foot per day (ft/d) & 0.3048 & meter squared per day \\
foot squared per day ( $\left.\mathrm{ft}^{2} / \mathrm{d}\right)$ & 0.09290 & \\
\hline
\end{tabular}

Sea Level: In this report, "sea level" refers to the National Geodetic Vertical Datum of 1929-a geodetic datum derived from a general adjustment of the first-order level nets of the United States and Canada, formerly called Sea Level Datum of 1929.

One nanosecond (ns) is equal to $10^{-9}$ second.

One megahertz $(\mathrm{MHz})$ is equal to $10^{6}$ hertz (cycles per second). 


\title{
Geohydrology of the Flints Pond Aquifer, Hollis, New Hampshire
}

\author{
By Joseph D. Ayotte and Tracy H. Dorgan
}

\begin{abstract}
Flints Pond has been subjected to accelerated eutrophication as a result of watershed development (in the form of new homes and the conversion of seasonal homes to permanent homes) since the 1930's. Ground water is the primary source of water for recharge to the 50-acre Flints Pond. Information on the geohydrology of the adjacent Flints Pond aquifer can be used in developing a water and nutrient budget for the pond-aquifer system, which could be used to design a remediation plan to improve the water quality of the pond. A detailed water-table map and an aquifer saturated-thickness and transmissivity map were produced. The saturated thickness and transmissive properties of the aquifer and altitude of the water table were determined by use of surface-geophysics, test-drilling, and aquifer-test data.
\end{abstract}

Ground-penetrating-radar surveys were done over more than 4 miles of the study area and on Flints Pond. Three distinct reflection signatures were commonly identifiable on the radar profiles: (1) thin, relatively flat-lying, continuous reflectors, which represent fine-grained lacustrine sediment draped over the underlying till or bedrock topography or overlying coarse-grained sediment; (2) subparallel to hummocky and chaotic reflectors, steeply dipping in places, which can represent coarse-grained ice-contact deposits such as eskers or crevasse fillings or can represent predominantly medium- to coarse-grained sands deposited as deltaic sediments in a lacustrine environment; and (3) sharply diffracted, fine-grained, chaotic reflectors, which represent till and (or) till over bedrock. The ground-penetrating-radar data indicated thick sequences of continuous reflectors that represent stratified drift from various depositional environments.
The ground-penetrating-radar data were used to determine the saturated thickness of the aquifer and, together with the test-drilling data, to construct a saturated-thickness map of the aquifer. The saturated thickness of the aquifer exceeds 90 feet in the northern part of the study area and averages 30 to 50 feet in the southern and eastern parts. The saturated thickness of the western part of the area is generally less than 10 feet.

Test borings were completed at 19 sites. Seven single wells and six nested-well pairs were installed in various lithologic units. Pond stage and water levels were measured monthly from April 1993 through November 1994. Water-level fluctuations over the period measured ranged from 0.67 foot in the middle of the aquifer to more than 5 feet towards the edges of the aquifer. A water-table map, constructed from data collected in November 1994, represents average ground-water levels in the aquifer.

Single-well aquifer tests were done at selected wells to determine horizontal hydraulic conductivity for the interval of aquifer-material tested. These test results compared favorably with the results from grain-size analysis. Horizontal hydraulic conductivities for stratified drift range from 2.8 to 226 feet per day. Horizontal-hydraulic conductivities are greatest at the south and west ends of the pond.

Horizontal hydraulic conductivities were quantitatively correlated to reflector signatures identified with ground-penetrating radar. From these correlations, transmissivities were estimated for areas where well data were unavailable but where ground-penetrating radar surveys were done. An aquifer saturated-thickness and transmissivity map for the study area indicates that transmissivity exceeds 3,000 squared feet per day in the southern and eastern-central parts of the aquifer. In the northern part, transmissivity ranges from 1,000 to 
2,000 squared feet per day. Transmissivity is generally less than 1,000 squared feet per day in the western part of the aquifer.

\section{INTRODUCTION}

Flints Pond, in Hollis, N.H. has been subjected to accelerated eutrophication as a result of watershed development since the 1930's. Most of the seasonal cottages that occupy the western shore have been converted to permanent homes, and recent development of the area west of Flint Pond Drive has added approximately 40 new homes. Dense growth of milfoil and other aquatic plants has greatly reduced the recreational value of the 50 -acre pond.

Ground-water flow is the primary recharge and discharge mechanism for Flints Pond. Surface-water inflow and outflow account for a small amount of the total flow through the pond and occur primarily when ground-water levels are high.

The U.S. Geological Survey (USGS), in cooperation with the New Hampshire Department of Environmental Services, Water Supply and Pollution Control Division, Biology Bureau (NHDES, WSPCD, Biology Bureau), did a geohydrologic investigation of the Flints Pond aquifer. A detailed map of saturated thickness and transmissivity was needed to characterize the flow system of Flints Pond and the surrounding aquifer. This information is needed for a thorough assessment of the hydrologic and nutrient budget for the system. The investigation will provide hydrogeologic information for any future nutrient-budget studies that may be done to help improve the water quality of the Pond.

The purpose of this report is to present the results of the USGS geohydrologic study of the Flints Pond aquifer, Hollis, N.H., from November 1992 through November 1994. The report quantifies the extent of the stratified-drift aquifer and the transmissive properties of the ground-water-flow system at Flints Pond. This report includes results of ground-penetrating radar (GPR), a water-table map, and a map of the saturated thickness and transmissivity of the aquifer in an approximately $1-\mathrm{mi}^{2}$ area around the pond.

Flints Pond and the Flints Pond aquifer are in east-central Hollis, north of the intersection of Broad Street and Flint Pond Drive (fig. 1). The area of the
Flints Brook drainage basin, from the outflow of Flints Pond, is approximately $4.98 \mathrm{mi}^{2}$. The northern boundary of the aquifer is a ground- and surface-water divide near the northern end of the study area. Small streams flow into the pond at the north end and at the southwest edge $(0.25 \mathrm{mi}$ north of Broad Street along Flint Pond Drive). The outflow, Flints Brook, is at the southern end of the pond.

A reconnaissance map of the availability of ground-water resources in the lower Merrimack River Basin was done by Cotton (1977), and the regional geohydrology of stratified-drift aquifers was studied by Toppin (1987). Koteff (1970) mapped the surficial geology of the Milford 15-minute quadrangle, which includes the northern part of the study area, and Koteff and Volckmann (1973) mapped the surficial geology of the Pepperell 7.5-minute quadrangle, including the southern part of the study area.

The authors thank the property owners in the Flints Pond area for their cooperation in granting USGS and NHDES personnel access to their property. The authors thank Matt Bowser and Steve Landry of the NHDES, WSPCD, Biology Bureau, for help with ground-penetrating-radar surveys and the collection of aquifer-test data, for measuring water levels, and for doing grain-size analyses of sediment samples collected during test drilling.

\section{APPROACH AND METHODS}

The geohydrology of Flints Pond was investigated by compiling previous data from within the study area and by collecting GPR, test-boring, water-level, and aquifer-test data. The areal extent of the stratified-drift aquifer was determined from previous mapping efforts (Koteff, 1970; Koteff and Volkman, 1973; Toppin, 1987).

The thickness of the stratified-drift aquifer was mapped by use of available domestic well records from the files of the NHDES, Water Resources Division, and by use of data from ground-penetrating-radar and test-drilling surveys for this study.

The hydraulic properties of the aquifer were assessed by analysis of grain-size distributions of sediment collected at selected points in the aquifer, by test drilling, and by analysis of results from single-well aquifer tests at observation wells installed for the study. 


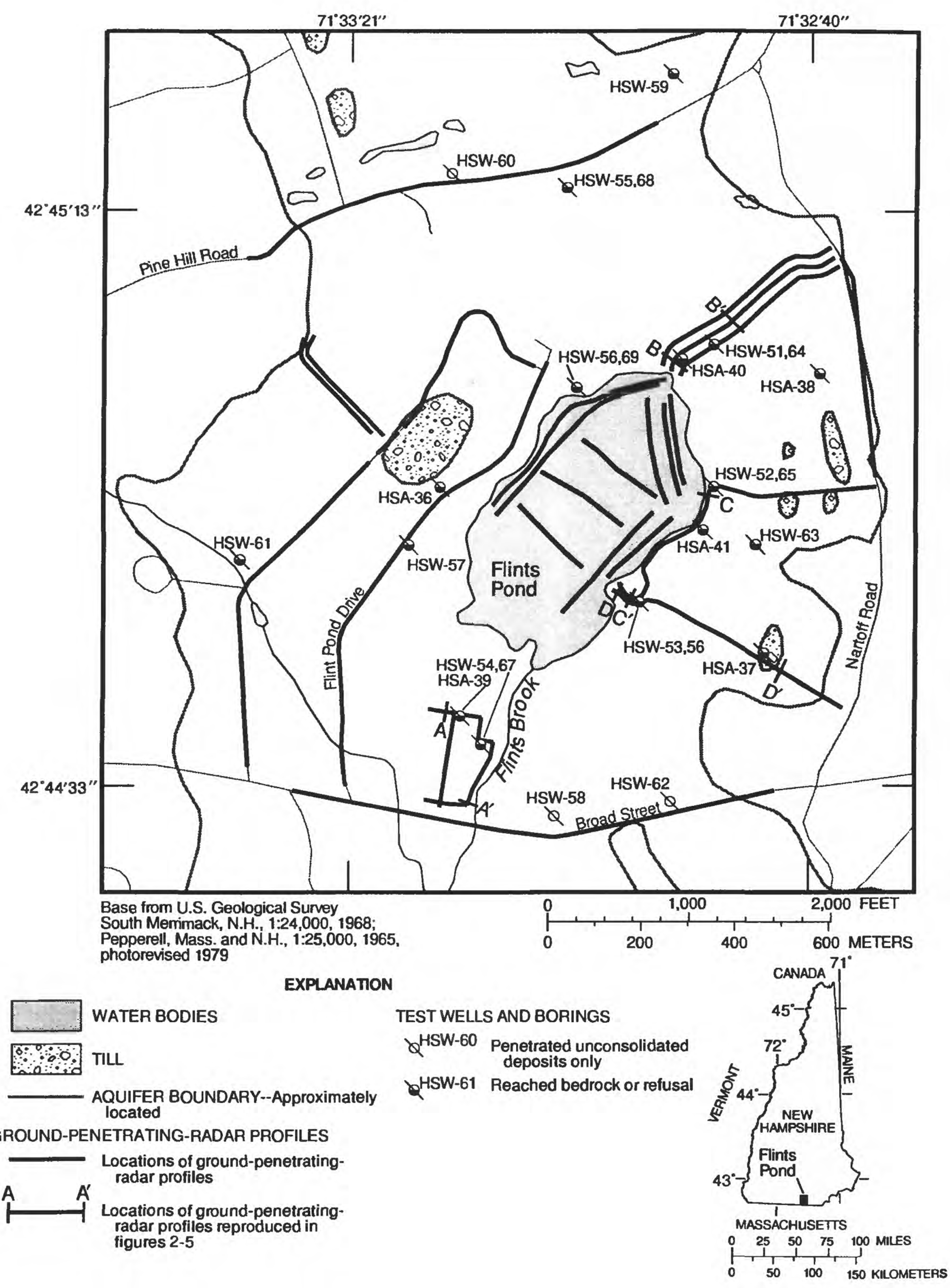

Figure 1. Location of study area, ground-penetrating-radar proflles, test borings, and observation wells near Flints Pond, Hollis, New Hampshire. 
These data were compared with the specific reflector types identified from the GPR data to generate additional hydraulic-conductivity and thickness data used to construct the saturated-thickness and transmissivity map.

\section{Ground-Penetrating-Radar Surveys}

GPR surveys were done along more than $4 \mathrm{mi}$. of land and water within the Flints Pond study area. The GPR equipment used in this investigation consisted of a Geophysical Survey Systems Inc. ${ }^{1}$ computer-controlled radar system, an 8-mm tape recorder, graphic recorder, and dual 80-Megahertz (MHz) antennas. Beres and Haeni (1991) described GPR theory and field operation, and Haeni (1992) details the use of GPR in environmental and engineering studies. Field workers who did the GPR surveys of Flints Pond used a 13-ft fiberglass boat with a small outboard motor to transport the electronic equipment; and dual $80-\mathrm{MHz}$ antennas were floated beside the boat. Land GPR surveys were done by towing dual $80-\mathrm{MHz}$ antennas behind a vehicle that contained the electronic equipment. Dual $80-\mathrm{MHz}$ antennas provided maximum signal penetration while maintaining enough resolution to detect and distinguish subsurface geologic features. The equipment was powered by one deep-cycle 12-volt battery. Profiling speeds ranged from 2 to $3 \mathrm{mi} / \mathrm{h}$. GPR surveys were located by selecting known landmarks at the beginning and end of the traverse, as well as known points along the traverse. Methods described by Beres and Haeni (1991) were used to interpret the GPR data.

\section{Test Drilling and Well Installation}

A test-drilling program was included to correlate results of the GPR surveys with lithologic logs and to install observation wells. Test drilling was done between December 18, 1992 and November 30, 1993. Test borings were made at 19 sites, and 7 single wells and 6 nested well pairs were installed in various lithologic units. Borings were made by use of 6-in.-outside-diameter hollow-stem augers. Lithologic logs were compiled for all wells and borings, and 50 split-spoon samples collected during test drilling were analyzed for grain-size distribution. All wells were constructed from 2-in.-inside-diameter Schedule 40 polyvinyl chloride pipe fitted with a 2.5 -ft-long screen. A screen slot size of $0.006 \mathrm{in}$. was used for fine-grained aquifer material and $0.010 \mathrm{in}$. for medium- to coarse-grained aquifer materials. Wells were backfilled with native materials. Attempts were made to minimize disturbance of the aquifer material during well installation by drilling down only to the desired depths, installing the well casing, and reversing the auger spin direction during auger removal. The wells were grouted with bentonite 5 to $10 \mathrm{ft}$ above the well screen.

\section{Grain-Size Analysis}

Split-spoon sediment samples from the Flints Pond aquifer were collected at 5 -ft intervals during test drilling. Each sample was dried and sieved to determine the grain-size distribution. Median grain diameter, degree of sorting, and standard deviation were calculated according to methods described by Folk (1974). Grain-size analyses were used to determine hydraulic conductivity for the aquifer by use of equations presented by Olney (1983). Hydraulic conductivity has a vertical and a horizontal vector component not accounted for by this equation. In this relation, an effective grain size $\left(D_{10}\right.$, in phi units) was used to estimate bulk (vectorless) hydraulic conductivity ( $K$, in squared feet per day) with the following equation:

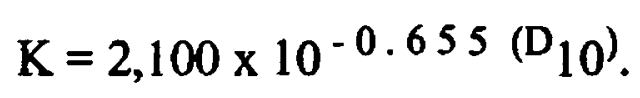

Effective grain size is defined as that grain size where 10 percent of the sample is finer than the effective grain size and 90 percent is coarser than the effective grain size. Olney (1983) developed this relation from permeameter tests of stratified-drift samples from Massachusetts. Moore (1990) found that this relation is consistent with other relations that have been developed between grain size-size distribution and bulk hydraulic conductivity (Krumbein and Monk, 1942; Bedinger, 1961; and Masch and Denney, 1966). Olney notes that comparisons with aquifer-test data, however, indicate that equation 1 may not give accurate results for very coarse-grained sand and (or) gravel. Olney (1983) developed a similar relation for the $D_{25}$, which is defined as the grain size where 25 percent of the sample is finer than the effective grain size and 75 percent is coarser than the effective grain size.

\footnotetext{
${ }^{1}$ Use of firm names is for identification purposes only and does not constitute endorsement by the U.S. Geological Survey.
} 
Bulk hydraulic conductivities based on $\mathrm{D}_{10}$ were estimated for 454 samples of stratified drift from southern New Hampshire by means of equation 1 and were plotted against median grain size in phi groups and according to degree of sorting (Ayotte and Toppin, 1995). Three arbitrary categories of sorting were chosen on the basis of the standard deviation of each individual sample.

Bulk hydraulic conductivities were then calculated for each median phi group and were averaged to determine a mean hydraulic conductivity per group (table 1). For example, the mean bulk hydraulic conductivity of sediment samples whose median grain size was described as medium sand and well sorted was $38 \mathrm{ft} / \mathrm{d}$ (the average of 25 and $51 \mathrm{ft} / \mathrm{d}$; table 1).

The values in table 1 were used to estimate bulk hydraulic conductivities from lithologic descriptions given in logs from test borings and wells (table 2). For example, for a lithologic description of $10 \mathrm{ft}$ of moderately sorted coarse sand overlying $20 \mathrm{ft}$ of well sorted fine sand overlying bedrock, the bulk hydraulic conductivities assigned would be $39 \mathrm{ft} / \mathrm{d}$ (the average of 30 and $48 \mathrm{ft} / \mathrm{d}$ ) and $9 \mathrm{ft} / \mathrm{d}$ (the average of 12 and $6 \mathrm{ft} / \mathrm{d}$ ), respectively. The estimate of transmissivity, based on the same description, would be $(10 \mathrm{ft} x$ $39 \mathrm{ft} / \mathrm{d})+(20 \mathrm{ft} \times 9 \mathrm{ft} / \mathrm{d})$, which equals $570 \mathrm{ft}^{2} / \mathrm{d}$.

\section{Single-Well Aquifer Tests}

Single-well aquifer tests were also used to determine the hydraulic conductivity of the aquifer materials. Single-well aquifer tests are done by instantaneously removing or adding a slug of water from the well casing and then monitoring the change in water level over time until the water level in the well stabilizes. Sixteen wells were tested to determine the horizontal hydraulic conductivity of various geohydrologic units in the study area.

Single-well aquifer tests done for this study were done by pressurizing the well casing with compressed air until the water level was depressed 1 to $2 \mathrm{ft}$ below the starting water level. When the water level was stable, the pressure was instantaneously released, simulating an instantaneous removal of a slug of water from the well casing. The resulting changes in water level were measured by a pressure transducer installed $5 \mathrm{ft}$ below the starting water level and recorded on a data collector at 1-second intervals until the water level was again stable. The duration of the tests ranged from a few seconds for coarse-grained aquifer materials to a few minutes for fine-grained aquifer materials and for till. The data were analyzed according to methods developed by Bouwer and Rice (1976) for unconfined aquifers and by Hvorslev (1951) for variable head in uniform aquifer material.

\section{GEOHYDROLOGIC SETIING}

Ground water flows through three geohydrologic units in the Flints Pond study area. These geohydrologic units are (1) stratified drift, the uppermost aquifer unit, which stores and transmits the largest quantities of water; (2) till, a discontinuous layer between the stratified drift and the bedrock surface that transmits only small amounts of water; and (3) bedrock, which transmits variable amounts of water, primarily through fractures in the rock.

\section{Stratified Drift}

The Flints Pond stratified-drift aquifer is composed of glaciofluvial and glaciolacustrine sands and gravels. Stratified drift of the Flints Pond aquifer fills a valley that was scoured by glacial ice. The valley was filled with meltwater from the retreating glacier, forming a glacial lake that was part of a larger glacial lake (glacial Lake Nashua) in the present-day Nashua River Valley. Separation of stratified-drift deposits by geographic position and altitude has been shown to be related to varying stages of a glacial lake in the area (Koteff and Volkman, 1973). The predominant glacial lake that controlled the deposition of stratified drift in the Flints Pond area was glacial Lake Nashua. This glacial lake formed between the till and (or) bedrock uplands to the south and the retreating ice margin to the north. Retreating ice uncovered successively lower outlets or spillways through which the glacial lake was drained, and outlet elevations are related to stages of lake drainage. Glacial Lake Nashua had six successively lower stages (Koteff and Volckmann, 1973) and the Flints Pond aquifer is composed of deposits associated with stages 5 and 6 of this lake; these stages and their related deposits are described in the following paragraphs. 
Table 1. Relation of mean bulk hydraulic conductivity to medlan grain slze and degree of sorting of stratlfied drift in New Hampshire

$[<$, less than; >, greater than; --, no data. Data from Ayotte and Toppin, 1995]

\begin{tabular}{clccc}
\hline & & \multicolumn{2}{c}{ Mean bulk hydraulic conductivity (K), in feet per day } \\
\cline { 3 - 5 } $\begin{array}{c}\text { Median } \\
\text { grain size } \\
\text { (phi units) }\end{array}$ & \multicolumn{1}{c}{$\begin{array}{c}\text { Median grain } \\
\text { description }\end{array}$} & $\begin{array}{c}\text { Well sorted } \\
\text { (standard deviation } \\
<1.25 \text { phi) }\end{array}$ & $\begin{array}{c}\text { Moderaty Sorted } \\
\text { (standard }\end{array}$ & $\begin{array}{c}\text { Poorly Sorted } \\
\text { (standard } \\
\text { deviation }\end{array}$ \\
\hline-1.75 & Granules & -- & 1.75 phi) & $>1.75$ phi) \\
-1.25 & Granules & -- & 320 & 49 \\
-.75 & Very coarse sand & 970 & 200 & 35 \\
-.25 & Very coarse sand & 470 & 120 & 25 \\
.25 & Coarse sand & 220 & 78 & 18 \\
.75 & Coarse sand & 110 & 48 & 13 \\
1.25 & Medium sand & 51 & 30 & 9 \\
1.75 & Medium sand & 25 & 19 & 7 \\
2.25 & Fine sand & 12 & 12 & 5 \\
2.75 & Fine sand & 6 & 7 & 3 \\
3.25 & Very fine sand & 3 & 4 & -- \\
3.75 & Very fine sand & 2 & 3 & -- \\
\hline
\end{tabular}

${ }^{1}$ Vectorless hydraulic conductivity calculated by use of methods described by Olney (1983).

Deposits associated with stage 5 of glacial Lake Nashua are primarily on the west side of Flints Pond. These deposits grade to a spillway elevation of approximately $205 \mathrm{ft}$ above sea level (Koteff and Volkman, 1973). On the basis of the upper $5 \mathrm{ft}$ of material, Koteff and Volckmann (1973) describe the deposits in the western part of the Flints Pond aquifer as pebble to boulder gravel. Detailed investigation has shown that this deposit is highly variable and that it includes significant sand deposits. Some of the gravels could have been removed by excavation, leaving sandy deposits exposed locally. Well records indicate that the stratified drift in the western area generally is less than $20 \mathrm{ft}$ thick and is unsaturated. Till, as well as some bedrock, is exposed in places throughout the western part of the aquifer.

As the ice margin retreated northwestward, exposing the area occupied by Flints Pond and the adjacent eastern aquifer area, a new, lower spillway was uncovered. This spillway lowered glacial Lake Nashua to approximately $190 \mathrm{ft}$ above sea level (Koteff and Volkman, 1973). Stage 6 deposits underlie most of Flints Pond and the east side of the Flints Pond aquifer. The deposits in this area consist of ice-contact coarse-grained stratified drift. These deposits are typically 40 to $80 \mathrm{ft}$ thick north and south of Flints Pond, as well as along the eastern shore. The aquifer thins to the east of Flints Pond, as do the deposits on the west side; this configuration indicates that the deep part of the aquifer is located along a thin north-to-south band running through the middle of the aquifer and pond.

TilI

Till is an unsorted mixture of clay, silt, sand, and rock fragments. It is varied in composition and degree of compactness. Two distinct tills have been recognized in the Pepperell quadrangle. The two tills are thought to represent two separate ice advances over southern New England (Koteff, 1970; Koteff and Volckmann, 1973). The lower till is generally compact and oxidized, and the upper till is generally sandy and unoxidized. The till, where present over the bedrock, represents the bottom of the Flints Pond stratified-drift aquifer.

\section{Bedrock}

The bedrock structure in the Flints Pond area trends approximately northeast-southwest, and includes 
one of the region's major faults known as the Flint Hill Fault, which trends northeast-southwest along the west edge of Flints Pond (Lyons and others, 1986). The bedrock in the study area consists of primarily the pre-Silurian to Early Devonian Berwick Formation of the Merrimack Group. The Berwick Formation consists of light- to dark-gray metasedimentary rocks such as phyllites, granulites, gneisses, and schists, which are locally intruded by granodiorite and binary granite (Lyons and others, 1986).

\section{GEOHYDROLOGY OF FLINTS POND AQUIFER}

The geohydrology of the Flints Pond aquifer was described by identifying (1) the altitude of the water table, (2) aquifer saturated thickness, and (3) aquifer transmissivity. Sources of data for this investigation included surficial geologic maps; GPR data; and lithologic logs and water-level data from wells, test borings, and single-well aquifer tests. The areal extent of the stratified drift in the study area was delineated by Koteff and Volckmann (1973). Maps of the water table and of the aquifer saturated thickness and transmissivity are presented and discussed in the sections that follow.

\section{Stratigraphy of Geohydrologic Units and Altifude of Water Table}

Data for the stratigraphy of geohydrologic units were obtained from available records of wells and borings within the study area, test drilling, and GPR. These data were used to delineate texturally different geohydrologic units within the stratified drift. Lithologic data for borings done in this investigation are shown in table 2.

Data for the altitude of the water table were obtained from water-level measurements made monthly at wells installed during test drilling.

\section{Stratigraphy, as Inferred from Ground-Penetrating- Radar Data}

Four GPR profiles are included in this report. The GPR data revealed thick sequences of continuous reflectors that represent stratified drift from various depositional environments, in various stratigraphic relations. Till and bedrock also are identifiable in some of the profiles.
The GPR surveys were done almost entirely within areas previously occupied by glacial Lake Nashua; therefore, coarse-grained ice-contact deposits identified by the GPR data are associated with fine-grained glacial-lake sediments. Three distinct reflection signatures were commonly identifiable on the radar profiles: (1) thin, relatively flat-lying, continuous reflectors, which represent fine-grained lacustrine sediment draped over the underlying till or bedrock topography or over coarse-grained stratified drift; (2) subparallel to hummocky and chaotic reflectors, steeply dipping in places, which probably represent coarse-grained ice-contact deposits such as eskers or crevasse fillings or represent predominantly medium- to coarse-grained sands deposited as deltaic sediments in a lacustrine environment; and (3) sharply diffracted, fine-grained, chaotic reflectors, which represent till and (or) till over bedrock.

Penetration depths of more than $800 \mathrm{~ns}$ (approximately $80 \mathrm{ft}$ ) were common on land-based surveys over stratified drift. Penetration depths of $400 \mathrm{~ns}$ (approximately $45 \mathrm{ft}$ ) were common on water surveys as a result of the attenuation of the radar signal by the water column.

Land-based GPR surveys provided a way to identify the top of bedrock in glacially scoured valleys that have been subsequently filled with thin till and stratified drift. The GPR surveys delineated the contact between stratified drift and the subjacent till and (or) bedrock, which extends to the land surface in some places. Typically, the GPR signal was attenuated as the antenna passed over the surface contact between stratified drift and till because of the increased electrical conductivity of the till.

The depths to various reflectors on the GPR profiles can be estimated if the propagation velocity of the electromagnetic waves is known. GPR electromagnetic wave propagation velocities were calculated at six test borings completed along various GPR surveys. The lithologic logs from these borings were used along with the two-way traveltime to reflectors in order to calculate propagation velocities by the equation

$$
\mathrm{V}=2 \mathrm{D} / \mathrm{t}
$$

where $\mathrm{V}$ is the GPR electromagnetic wave-propagation velocity, in feet per nanosecond, $D$ is the thickness of a subsurface reflector, in feet, and $t$ is the two-way traveltime, in nanoseconds (Beres and Haeni, 1991). 


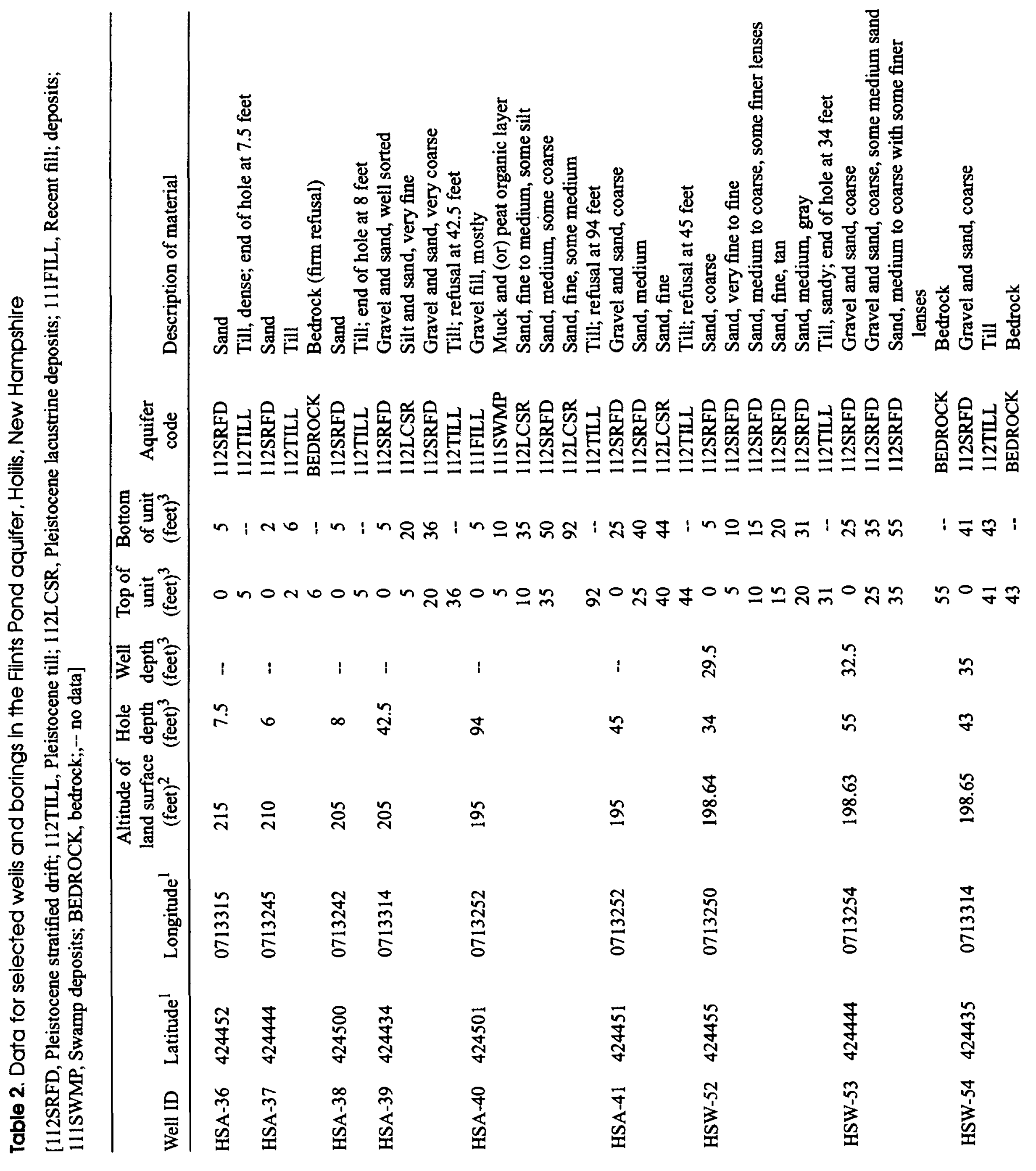




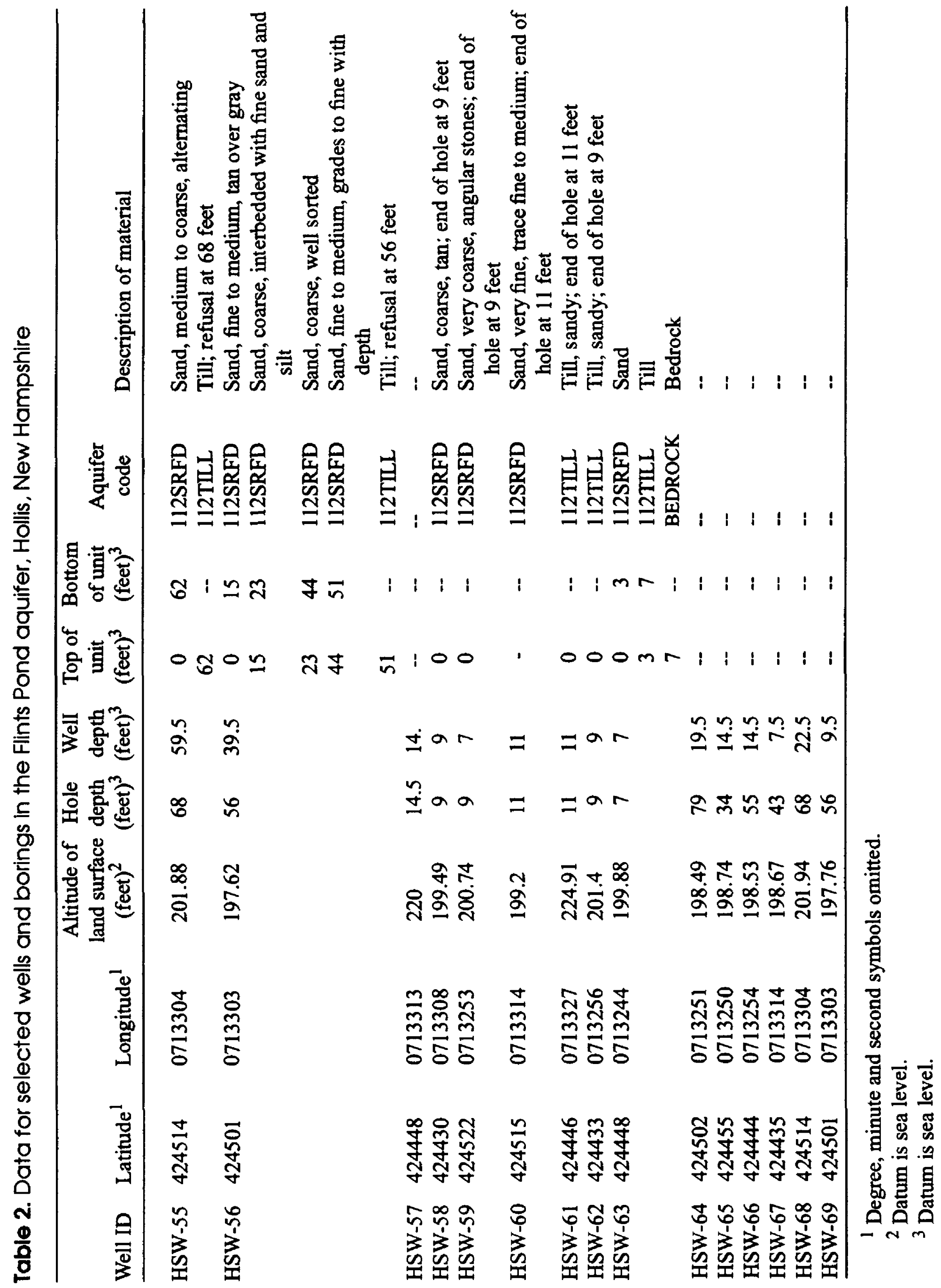


Table 3. Ground-penetrating-radar propagation velocities of saturated stratified drift near Fiints Pond. Holiis, New Hampshire

[GPR, ground-penetrating radar]

\begin{tabular}{cccc}
\hline $\begin{array}{c}\text { Well or boring } \\
\text { identifier } \\
\text { (fig. 1) }\end{array}$ & $\begin{array}{c}\text { Depth from top of water table } \\
\text { to top of till and (or) bedrock } \\
\text { surface, in feet }\end{array}$ & $\begin{array}{c}\text { Two-way traveltime of GPR } \\
\text { pulse, in nanoseconds }\end{array}$ & $\begin{array}{c}\text { GPR propagation velocity, in } \\
\text { feet per nanosecond }\end{array}$ \\
\hline HSA-39 & 42.5 & 472.7 & .18 \\
HSA-41 & 45 & 446.6 & .20 \\
HSW-51 & 79 & 752.4 & .21 \\
HSW-52 & 34 & 359.2 & .19 \\
HSW-53 & 55 & 533.9 & .21 \\
HSW-54 & 43 & 484.8 & .18 \\
\hline
\end{tabular}

GPR propagation velocities calculated for saturated stratified drift (from the top of the water table to the top of the interpreted till and (or) bedrock reflector) for each test boring are shown in table 3 . The calculated velocities range from 0.18 to $0.21 \mathrm{ft} / \mathrm{ns}$, and the average is $0.2 \mathrm{ft} / \mathrm{ns}$. These velocities are in the range reported by Beres and Haeni (1991) and by Barr (1993) for saturated, unconsolidated sediment. Hansen (1993) used a value of $0.2 \mathrm{ft} / \mathrm{ns}$ for saturated, unconsolidated sediment to interpret GPR data in central Massachusetts.

Unprocessed GPR profile A-A' (fig.2), is located near the south end of Flints Pond (fig. 1). Hummocky, chaotic reflectors near the surface (0 to $50 \mathrm{ns)}$ ) represent coarse-grained fluvial sediments that overlie fine-grained deposits near test boring HSA-39. Thin and continuous, parallel reflectors at about 50 to $200 \mathrm{~ns}$ on the west side of the profile show the thickness and extent of the fine-grained glacial-lake-bottom sediments. The lake-bottom-sediment reflections are draped over hummocky, chaotic, coarse-grained reflectors at about 200 to $400 \mathrm{~ns}$ that represent coarse-grained, ice-contact stratified drift: the subsurface part of the stage 6 deposits (Koteff and Volckmann, 1973), such as crevasse fillings. The thick, dark triple bands beneath the hummocky reflectors represent till and (or) bedrock. The lithologic log from test boring HSA-39 indicates coarse-grained sand and gravel from 0 to $5 \mathrm{ft}$, very fine grained sands and silt from 5 to $20 \mathrm{ft}$, and coarse-grained sands grading to fine gravel from 20 to $37 \mathrm{ft}$. Compact, silty till was found in the sampler at $37 \mathrm{ft}$. The hole was continued through the till to refusal at a depth of $42.5 \mathrm{ft}$. The GPR profile A-A', at test well HSW-54 (fig. 2), indicates coarse-grained sediments from 0 to approximately 400 ns. Lithologic data from test well HSW-54 indicate well sorted, coarse- to very coarse-grained sand and fine gravel to approximately $40 \mathrm{ft}$. Till was found at $40 \mathrm{ft}$, and refusal was reached at $43 \mathrm{ft}$. The two test borings shown on this section are separated by only $300 \mathrm{ft}$ but have markedly different lithologies. Fine-grained sediment overlaps the ice-contact deposits, as shown in figure 2 .

Unprocessed GPR profile B-B' (fig. 3), located near the north end of the pond (fig. 1), shows reflectors similar to those found on profile A-A'. Thin, flat-lying reflectors between 25 and $75 \mathrm{~ns}$ on the west side of the profile indicate fine to medium sand mapped as stage 5 deposits by Koteff and Volckmann (1973). Beneath these thin lake-bottom sediments are steeply dipping, parallel to hummocky reflectors that are found from about 75 to $275 \mathrm{~ns}$; these reflectors represent predominantly medium-grained sands and indicate dipping beds, 25 to $50 \mathrm{ft}$ thick. Strong flat-lying, parallel reflectors from about 275 to $750 \mathrm{~ns}$, near well HSW-51, show very fine grained sands and silt that fill the glacially scoured valley. The strong reflectors have high amplitudes that are probably the result of the increased contrast in electrical resistivity of alternating clay, silt, and fine-sand laminae; they are not related to 


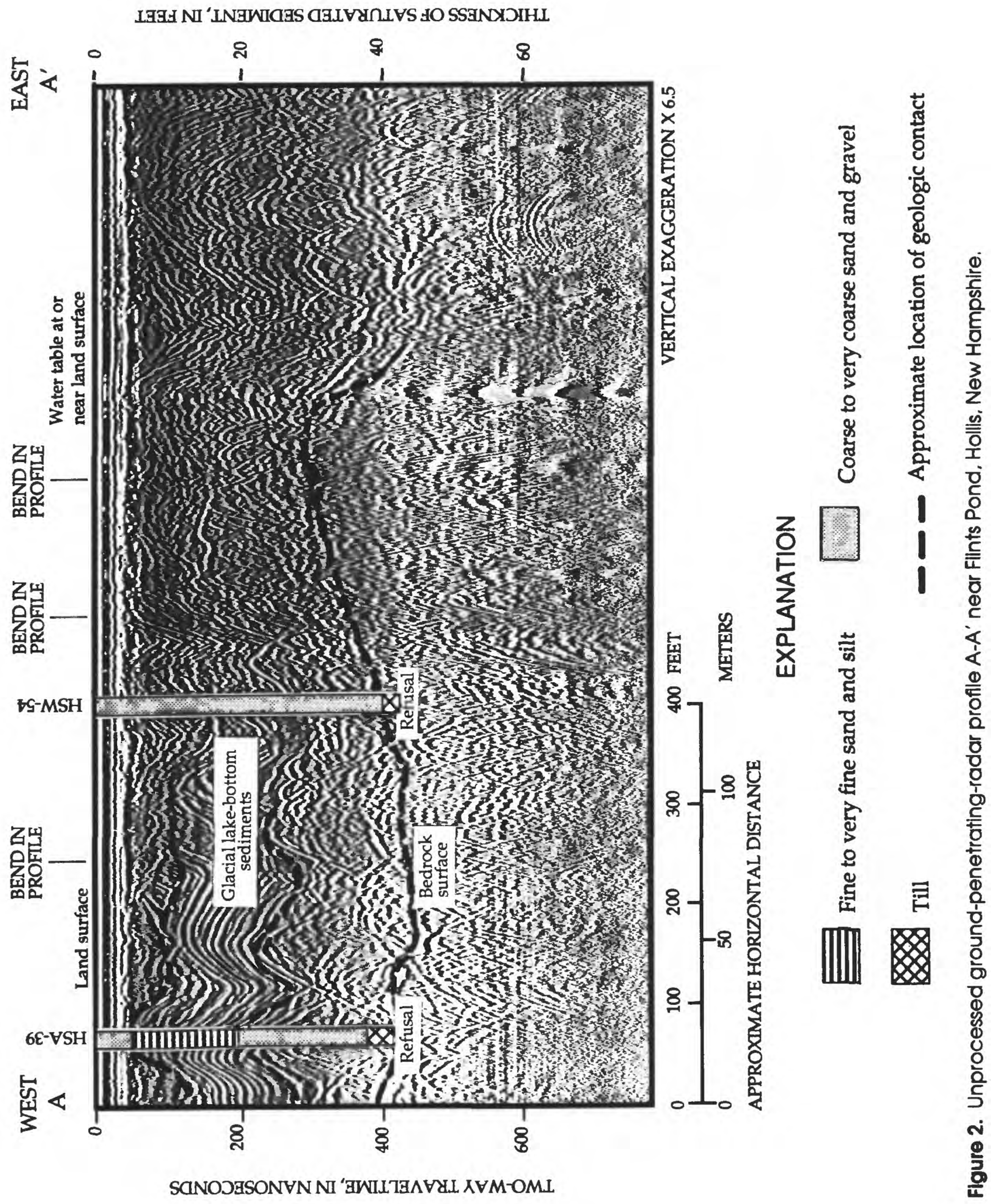




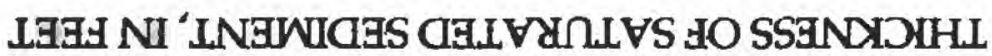
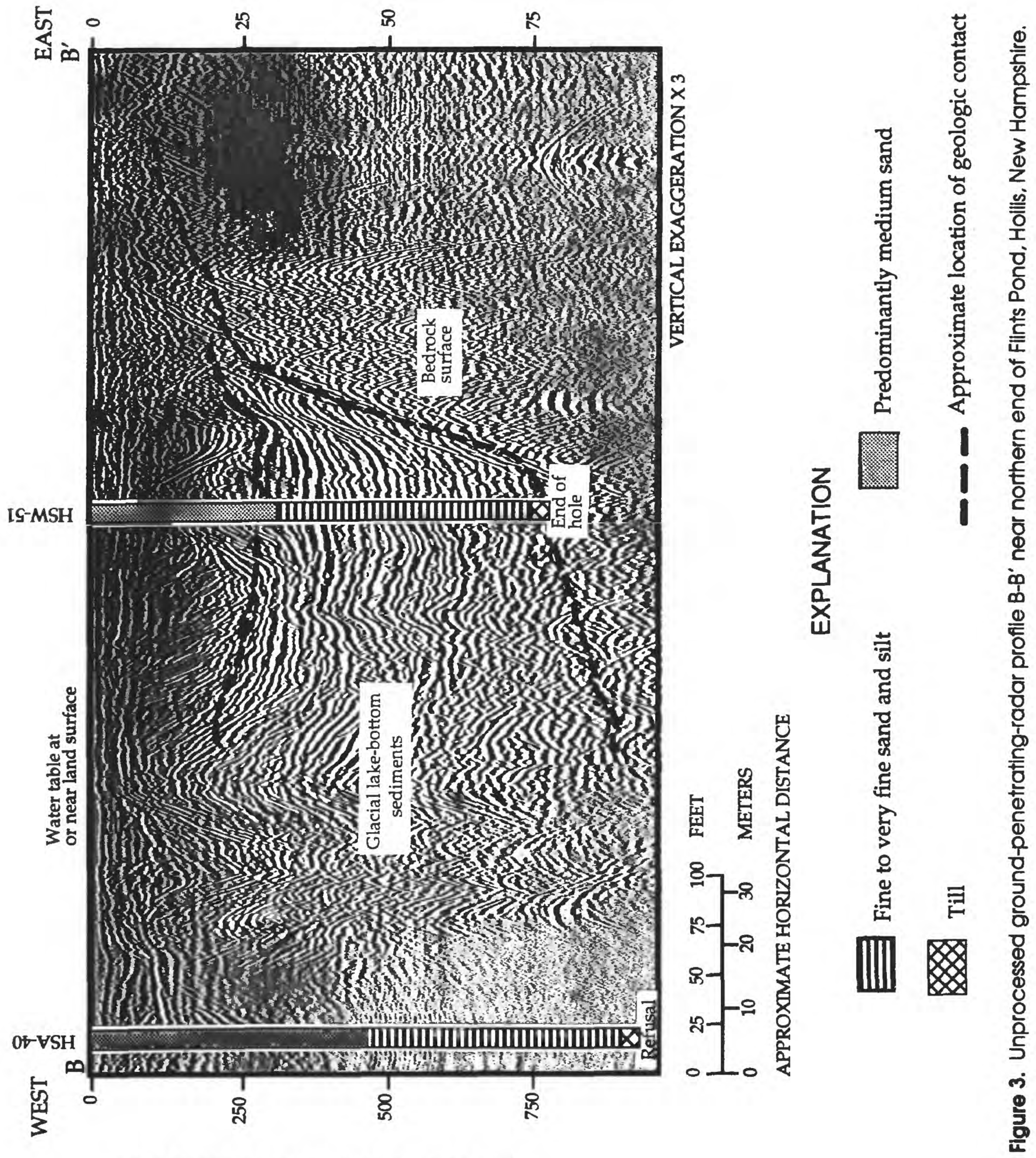

SANOJBSONVN NI'BWILTA $\Lambda$ YII XVM-OMI 
bedding thickness in this case. Near test boring HSA- 40 (fig. 3), the GPR did not penetrate to bedrock, which is $94 \mathrm{ft}$ below land surface. The lithologic log from test boring HSA-40 revealed medium-grained sand overlying fine sand and silt. The bedrock surface is identifiable east of test boring HSA-40 and is traceable to the end of the record. The mapped surfacegeologic contact between stratified-drift and till (aquifer boundary) near profile $B-B^{\prime}$ is shown on figure 1 . Profile B-B', however, shows a sharp rise in the bedrock surface approximately $100 \mathrm{ft}$ northeast of well HSW-51 . This rise shows the stratified drift to be thin to the east of well HSW-51 and indicates that the deep part of the aquifer is confined to a narrow north-south zone in line with the pond.

Unprocessed GPR profile C-C' (fig. 4) is located along the east side of Flints Pond (fig. 1). The stratified drift in this area was mapped as stage 6 deposits of glacial Lake Nashua (Koteff and Volckmann, 1973). The GPR data for profile C-C' reveal several structures associated with various depositional environments. Near test well HSW-52, alternating parallel and hummocky reflectors indicate alternating fine- to coarse-grained sand layers. Near test boring HSA-41, hummocky reflectors from 0 to about 200 ns grade into steeply dipping, parallel-to-subparallel reflectors at about 200 to $450 \mathrm{~ns}$. These reflector sequences indicate coarse-grained sand and gravel $(0-25 \mathrm{ft})$ grading vertically to medium- and fine-grained sands and then ending in till at $45 \mathrm{ft}$. The moderately diffracted upper part of the profile between test boring HSA-41 and test well HSW-53 (fig. 4) is masked by hyperbolic patterns from single-point reflectors-probably large cobbles at approximately $8 \mathrm{ft}$ below land surface.

A coarse-grained ice-contact deposit is identified in cross section by profile D-D' (fig. 5), near test well HSW-53 (fig. 1). The steeply dipping, subparallel reflectors at 0 to $380 \mathrm{~ns}$ represent a cross section through the coarse-grained ice-contact feature, identified on the west end of profile C-C'. The lithologic log of test well HSW-53, drilled through the center of the deposit, indicates very coarse grained sand to fine gravel from 0 to $40 \mathrm{ft}$. Results of sediment analysis of samples collected during test drilling indicates that the median grain diameter is between 1.4 and $0.71 \mathrm{~mm}$. The stratigraphy identified by the GPR data and the sediment grain sizes determined from test drilling indicate that the deposit probably is an ice-contact channel filling or a body of ice-contact deltaic sediments.

The GPR profile east of test well HSW-53 shows flat-lying, parallel reflectors at about 100 to $225 \mathrm{~ns}$. This pattern indicates that fine-grained glacial lake-bottom sediment is in contact with the coarse sediment near well HSW-53. The overlying hummocky reflectors represent coarse-grained fluvial deposits. Thick, dark, continuous multiple-band reflectors at about 450 to $500 \mathrm{~ns}$ on the western edge of the profile represent the till and (or) bedrock surface. This reflector is traceable to the near surface (approximately $75 \mathrm{~ns}$ ) on the east end of the profile. The surficial stratified-drift and till contact is identifiable on profile D-D' at the point where the generally hummocky reflectors change abruptly to sharply diffracted reflectors at approximately $75 \mathrm{~ns}$. This point coincides with the maximum extent of glacial Lake Nashua mapped by Koteff and Volckmann (1973) at this location.

\section{Altitude of Water Table}

Water-level measurements at the 13 wells were made monthly from April 1993 through November 1994 to determine ground-water altitudes and fluctuations near the pond; the stage at the pond outlet also was measured. Pertinent well and boring data were added to the Ground-Water Site Inventory (GWSI) data base maintained by the USGS. Each well is cross-referenced to a site-identification number and to any other pertinent information about the site.

The altitude of the water table from measured wells ranged from $193.7 \mathrm{ft}$ in well HSW-62 (fig. 1) to $221.8 \mathrm{ft}$ in well HSW-61 (fig. 1). Water levels fluctuated from less than $1 \mathrm{ft}$ in the middle of the aquifer to more than $5 \mathrm{ft}$ toward the edges of the aquifer. A water-table map constructed from data collected in November 1994 represents average water levels in the aquifer (fig. 6).

\section{Hydraulic Characteristics of Flints Pond Aquifer}

Saturated thickness, hydraulic conductivity, and transmissivity of the stratified-drift aquifer were determined by integrating GPR data with drilling and single-well aquifer-test data. GPR data were used to 


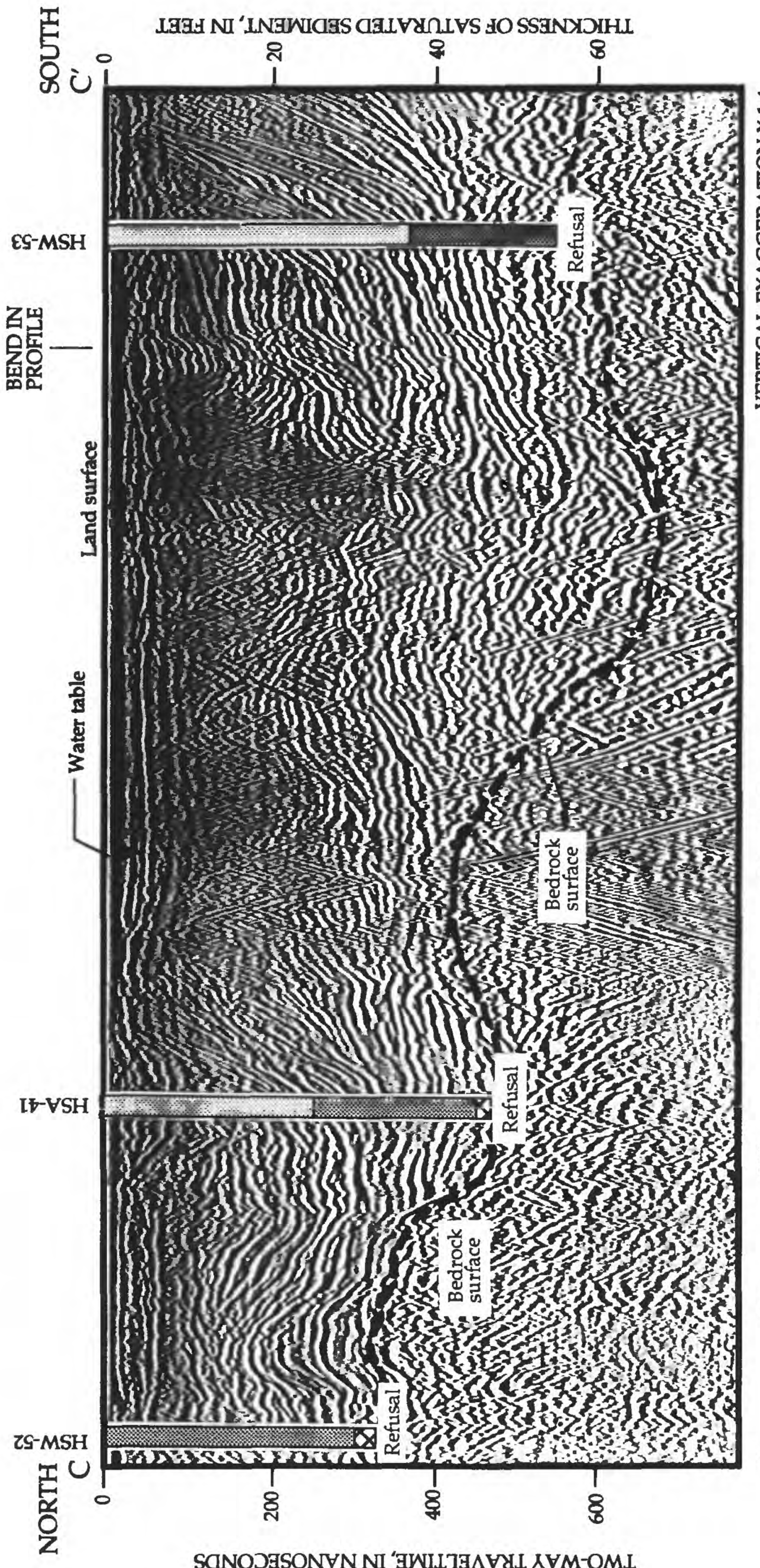

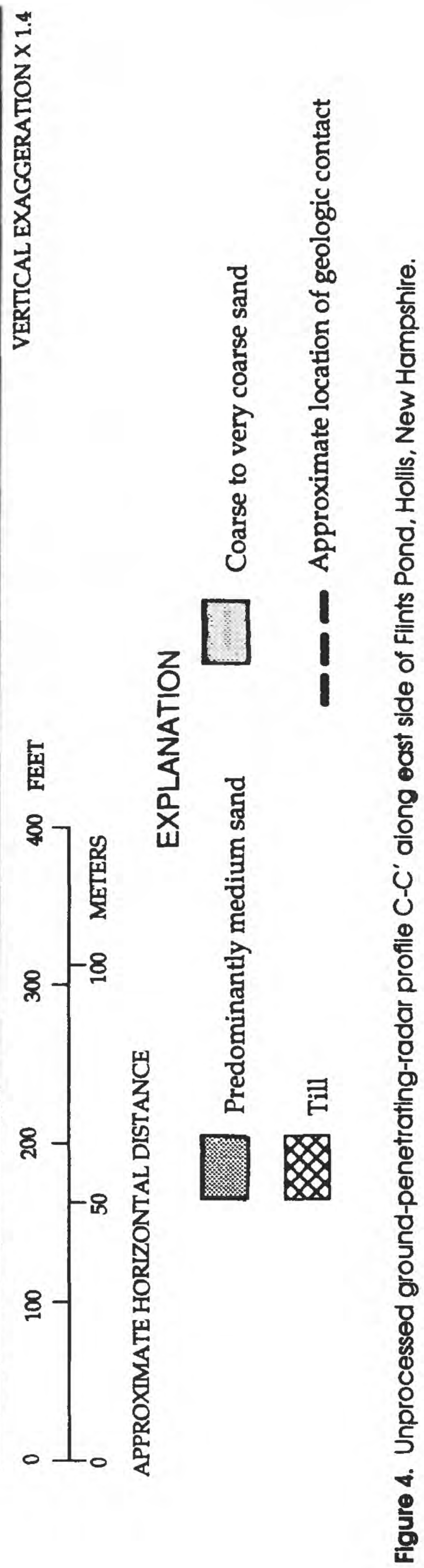




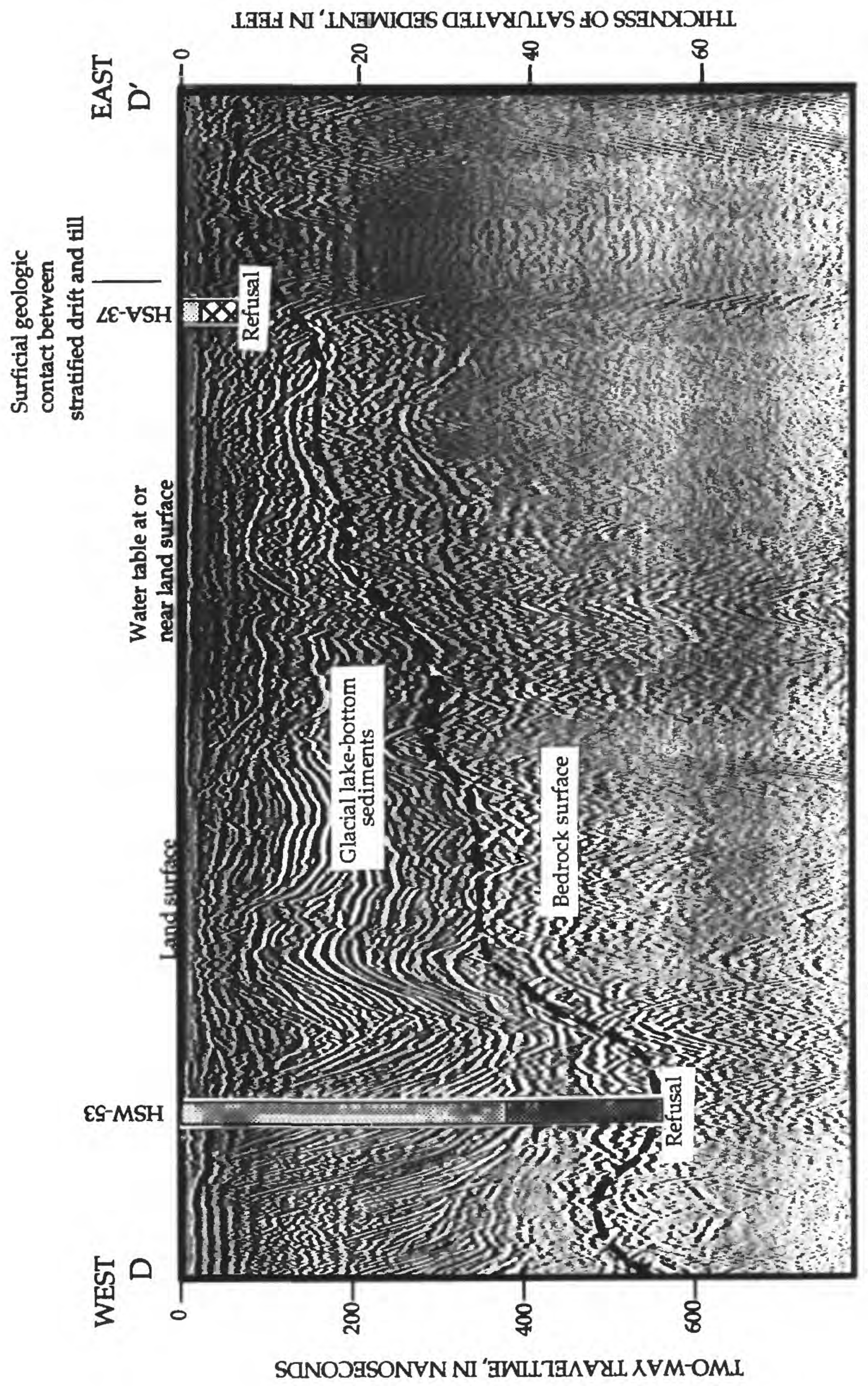

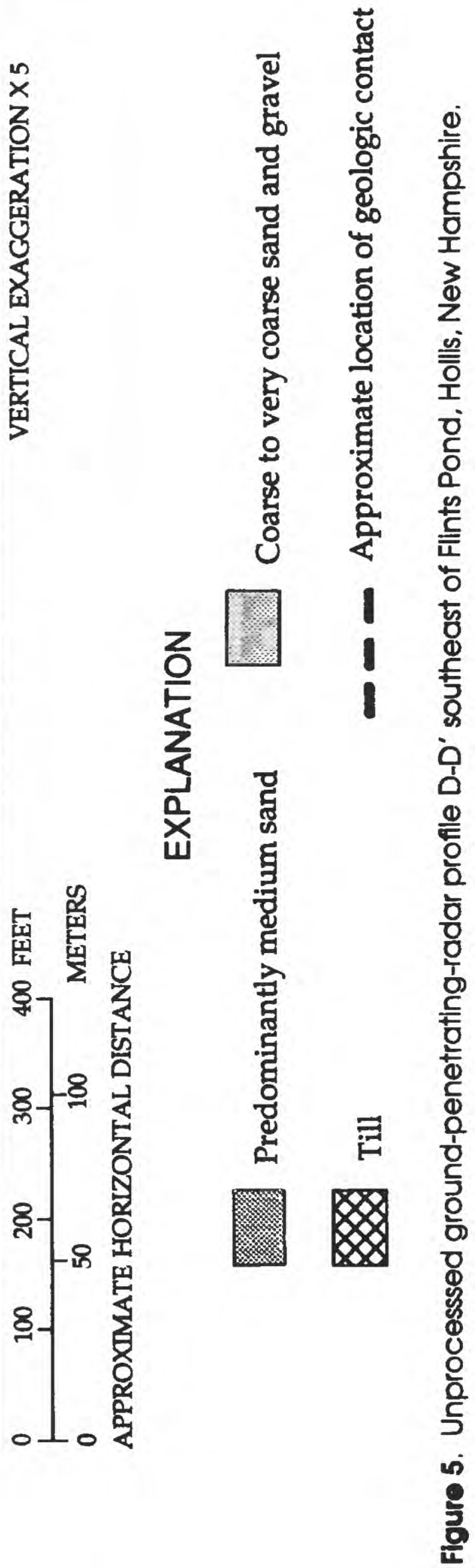




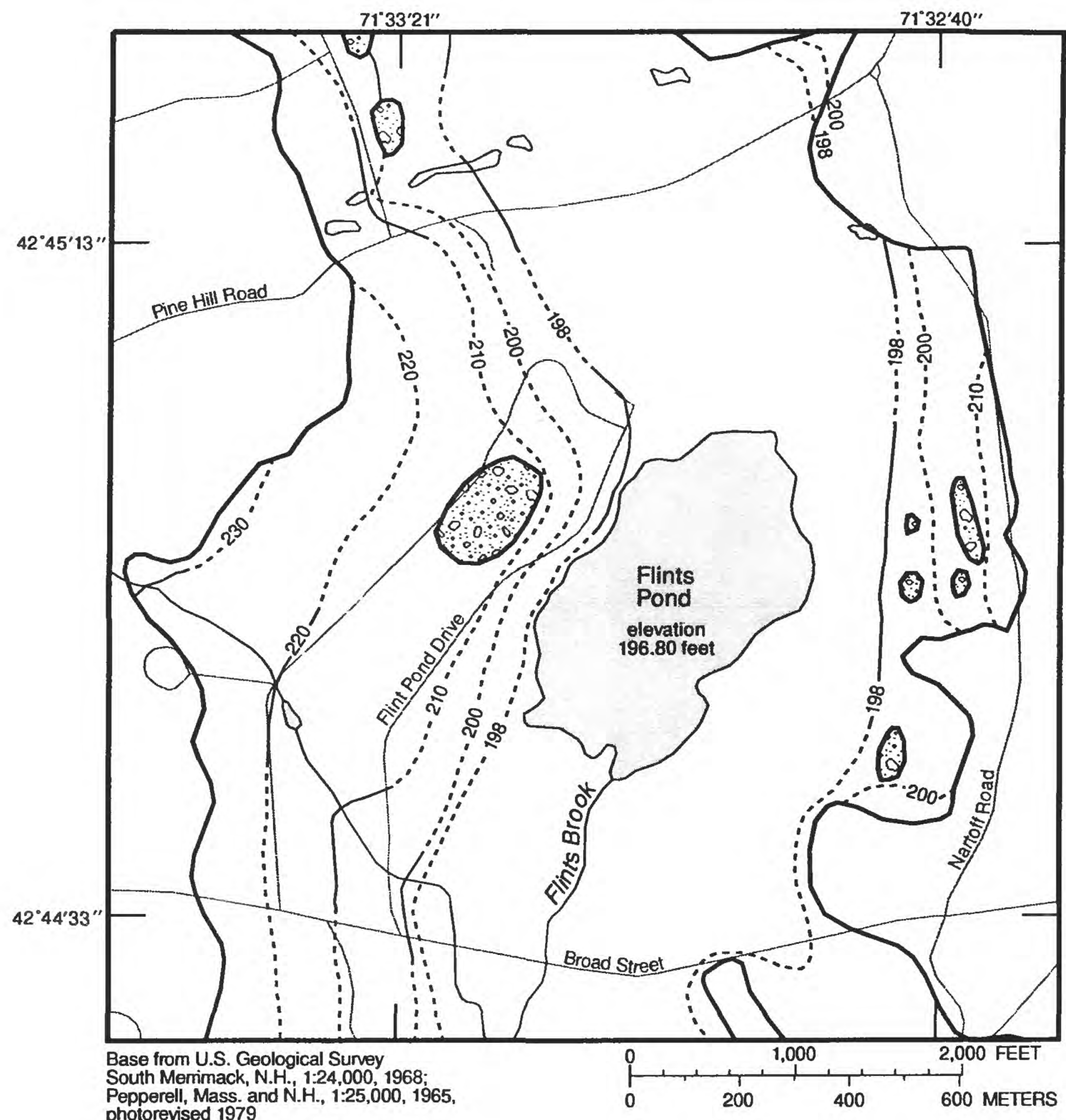

EXPLANATION

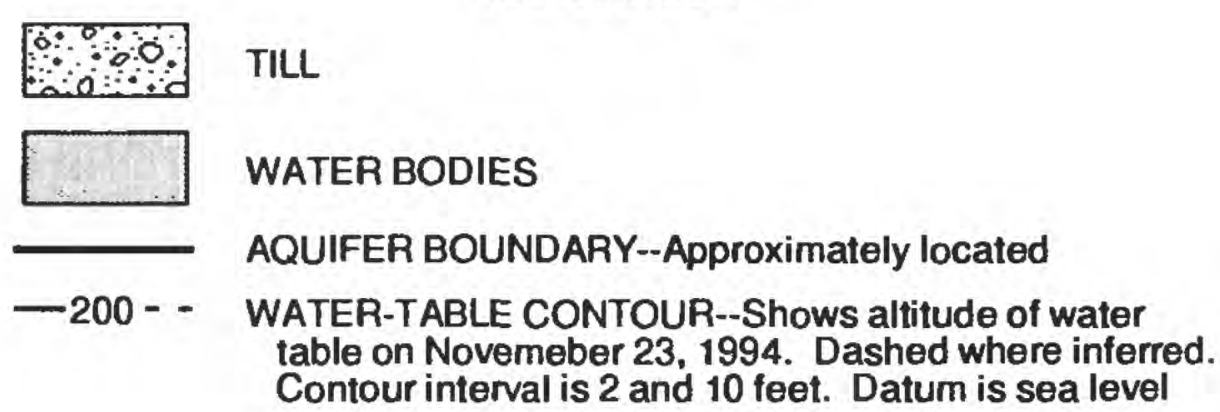

Figure 6. Altitude of water table for the Flints Pond aquifer, Hollis, New Hampshire, on November 23, 1994. 
identify depositional environments of the geohydrologic units; depositional environments are related to the hydraulic and transmissive properties of the aquifer materials. Comparisons between geohydrologic units and their respective depositional environments (identified with GPR) and hydraulic properties (identified by analysis of samples collected during test drilling and by single-well aquifer testing) allowed development of a conceptual model of the horizontal and vertical distribution of hydraulic conductivity.

\section{Saturated Thickness}

The saturated thickness of an unconfined stratified-drift aquifer is the vertical distance between the water table and the base of the aquifer. The base of a stratified-drift aquifer is generally the contact between the stratified drift and the till and (or) bedrock surface. The saturated thickness (fig. 7) is greater than $90 \mathrm{ft}$ at the north end of the pond and is 30 to $50 \mathrm{ft}$ at the south end of the pond. This configuration indicates that the bedrock valley, which is now filled with stratified drift, may have been overdeepened by glacial scour or that the preglacial drainage was to the north. West and east of the pond, the saturated thickness abruptly decreases to less than $10 \mathrm{ft}$ (fig. 7). West of Flints Pond Drive, on the west side of the pond, the saturated thickness is effectively zero.

\section{Hydraulic Conductivity and Transmissivity}

Transmissivity is the rate at which water at the prevailing kinematic viscosity can be transmitted through a unit width of an aquifer under a unit hydraulic gradient (Lohman and others, 1972). The transmissivity $(\mathrm{T})$ of an aquifer is equal to the saturated thickness (b), in feet, multiplied by the horizontal hydraulic conductivity $(\mathrm{K}$, a directional measure of the permeability), in feet per day, and is expressed in squared feet per day; thus,

$$
\mathrm{T}=\mathrm{K}(\mathrm{b}) \text {. }
$$

Transmissivity at a specific site was derived by multiplying estimates of hydraulic conductivity of lithologic units in the aquifers by saturated thickness. Hydraulic conductivity, in turn, was estimated from grain-size distributions of aquifer material samples by use of the regression equation developed by Olney (1983) and from analysis of single-well aquifer-test data.

The transmissivity of the Flints Pond aquifer exceeds $3,000 \mathrm{ft}^{2} / \mathrm{d}$ and is greatest in the middle of the aquifer, immediately south of the pond. Immediately north of the pond the saturated thickness is greater than 90 feet and the transmissivity ranges from 1,000 to $2,000 \mathrm{ft}^{2} / \mathrm{d}$. Elsewhere in the aquifer, especially near the west and east edge, transmissivity is less than $1000 \mathrm{ft}^{2} / \mathrm{d}$. The zone of greatest transmissivity does not coincide with the greatest saturated thickness.

\section{Estimates Based on Grain-Size Anaiysis}

Hydraulic conductivity in the Flints Pond aquifer, estimated from grain-size distributions of 50 samples of aquifer materials, ranged from 3 to $273 \mathrm{ft} / \mathrm{d}$. Selected values of bulk hydraulic conductivities from grain size analysis are listed in table 4.

Very fine sand, silt, and clay deposits in the study area were not analyzed for grain-size distribution because their hydraulic conductivities are low (less than $4 \mathrm{ft} / \mathrm{d}$ ) and, therefore, considered insignificant in terms of total transmissivity (Todd, 1980).

\section{Estimates Based on Single-Well Aquifer Tests}

The estimates of horizontal hydraulic conductivity as determined by the Bouwer and Rice method range from $2.0 \mathrm{ft} / \mathrm{d}$ for fine-grained stratified drift to $226 \mathrm{ft} / \mathrm{d}$ for coarse-grained, moderately sorted coarse to very coarse sand. Estimates of horizontal hydraulic conductivity determined by the Hvorslev (1951) method ranged from $2.3 \mathrm{ft} / \mathrm{d}$ for fine-grained stratified-drift and $262 \mathrm{ft} / \mathrm{d}$ for coarse-grained, moderately sorted coarse to very-coarse sand. The results from the Bouwer and Rice method compare closely to the results from the Hvorslev method. Horizontal hydraulic conductivities at wells screened in till averaged $0.45 \mathrm{ft} / \mathrm{d}$ for the Bouwer and Rice method and $0.62 \mathrm{ft} / \mathrm{d}$ for the Hvorslev method. The results of the single-well-aquifer-test analyses compare favorably to results from grain-size analysis (table 4). materials that show as strong, flat-lying, parallel reflectors that indicate the presence of very fine grained sands and silt. The hydraulic conductivity, calculated from methods developed by Bouwer and Rice (1976), is $2.8 \mathrm{ft} / \mathrm{d}$; the range of estimates is 2.8 to $12 \mathrm{ft} / \mathrm{d}$. 


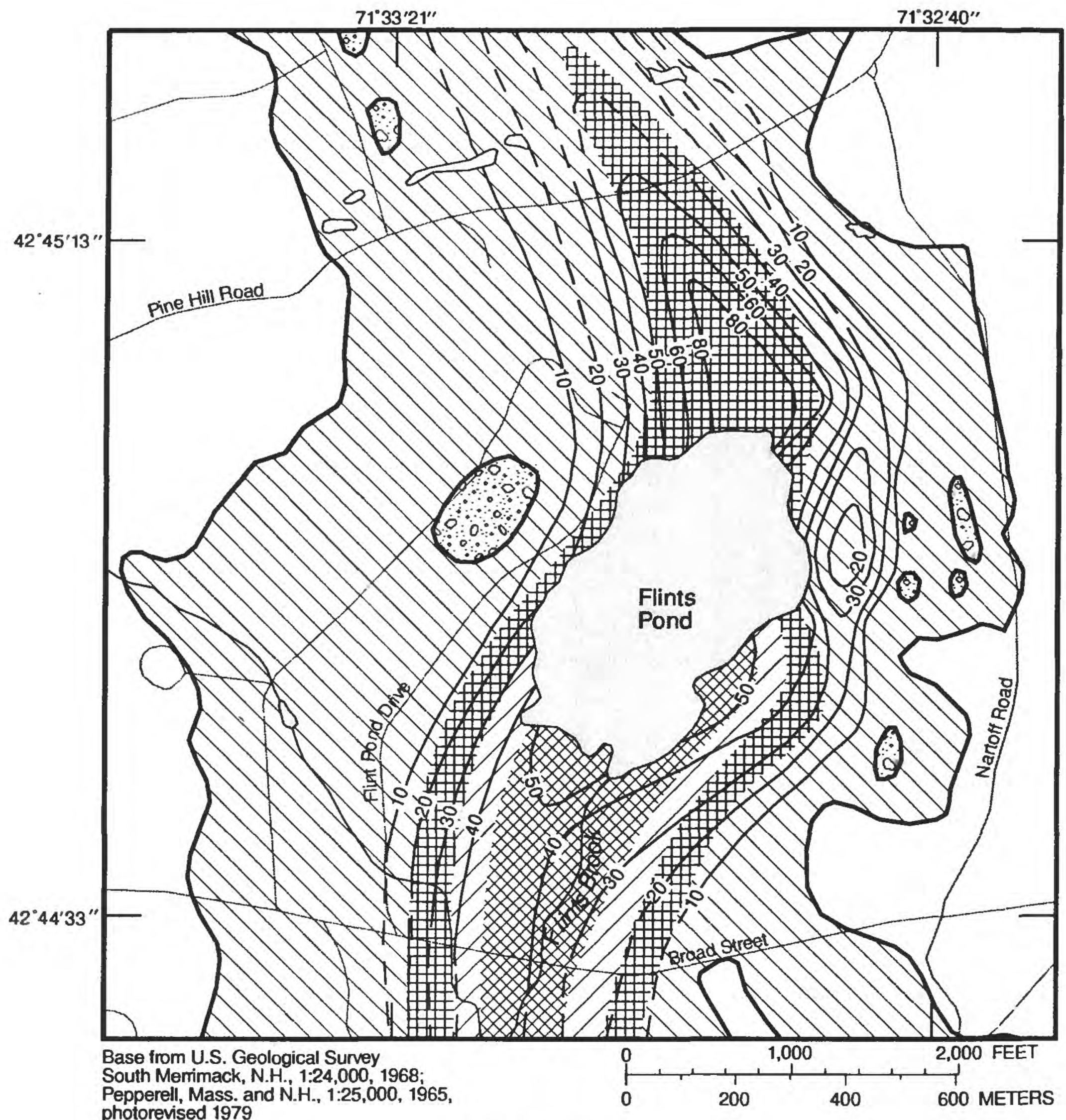

EXPLANATION

TRANSMISSIVITY OF STRATIFIED
AQUIFER (feet squared per day)
1,000 to 2,000
$>2,000$ to 3,000
$>3,000$

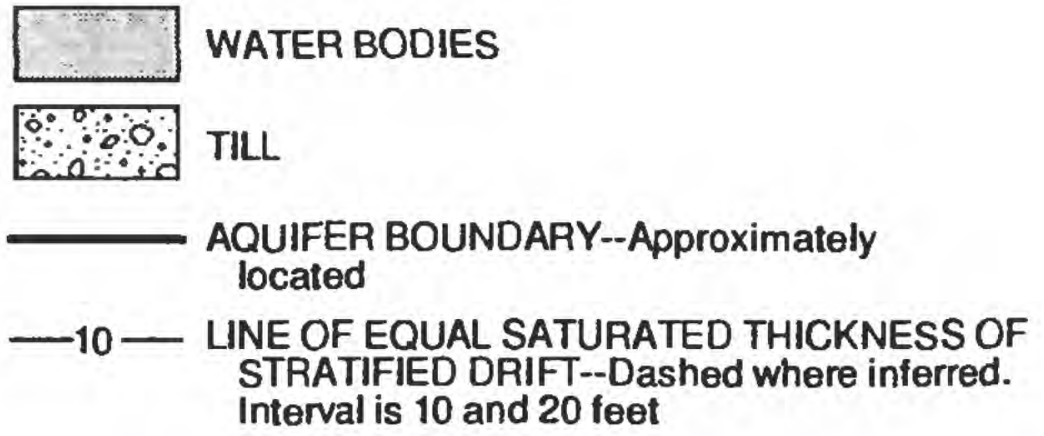

Figure 7. Saturated thickness and transmissivity zones, Flints Pond aqulfer, Hollis, New Hampshire. 
Table 4. Summary of estimated hydraulic conductivities from grain-size analyses, well-log descriptions, and single-well aquifer tests for selected wells in the Flints Pond aquifer, Hollis, New Hampshire

[ft, feet; ft/d, feet per day; --, no data available]

\begin{tabular}{|c|c|c|c|c|c|c|}
\hline \multirow{3}{*}{$\begin{array}{l}\text { Well identifier } \\
\text { (fig.1) }\end{array}$} & \multirow{3}{*}{$\begin{array}{l}\text { Interval tested } \\
\text { (ft) }\end{array}$} & \multicolumn{5}{|c|}{ Estimated hydraulic conductivity by given method } \\
\hline & & \multicolumn{2}{|c|}{ Grain-size analysis ${ }^{1}$} & \multirow[b]{2}{*}{$\begin{array}{l}\text { Well-log } \\
\text { description } \\
\text { (ft/d) }\end{array}$} & \multicolumn{2}{|c|}{ Single-well aquifer test } \\
\hline & & $\begin{array}{c}\text { Based on } \\
D_{10}{ }^{2} \\
\text { (ft/d) }\end{array}$ & $\begin{array}{c}\text { Based on } \\
\mathrm{D}_{25^{3}} \\
(\mathrm{ft} / \mathrm{d})\end{array}$ & & $\begin{array}{c}\text { Bouwer and } \\
\text { Rice, } 1976 \\
(\mathrm{ft} / \mathrm{d})\end{array}$ & $\begin{array}{c}\text { Hvorslev, } \\
1951 \\
\text { (ftdd) }\end{array}$ \\
\hline HSW-51 & $37-39.5$ & 4 & 6 & 12 & 2.8 & 3.7 \\
\hline HSW-52 & $27-29.5$ & - & - & 15 & 2.0 & 2.3 \\
\hline HSW-53 & $30-32.5$ & 14 & 118 & 100 & 45.7 & 68.1 \\
\hline HSW-54 & $32.5-35$ & - & -- & -- & 100 & 106 \\
\hline HSW-55 & $57-59.5$ & 6 & 15 & 30 & 26.0 & 56.1 \\
\hline HSW-56 & $37-39.5$ & 60 & 150 & 40 & 35.0 & 47.7 \\
\hline HSW-58 & $6.5-9$ & 273 & 427 & 220 & 186 & 262 \\
\hline HSW-59 & $4.5-7$ & 58 & 340 & 40 & 43.8 & 76.9 \\
\hline HSW-60 & $8.5-11$ & - & -- & 3 & .42 & .57 \\
\hline HSW-62 & $6.5-9$ & - & - & -- & .48 & .67 \\
\hline HSW-64 & $17-19.5$ & 28 & 39 & 25 & 64.0 & 79.5 \\
\hline HSW-65 & $12-14.5$ & 52 & 54 & 37 & 11.5 & 23.8 \\
\hline HSW-66 & $12-14.5$ & 245 & 481 & 220 & 226 & 251 \\
\hline HSW-67 & $5-7.5$ & 118 & 150 & 25 & 31.0 & 42.6 \\
\hline HSW-68 & $20-22.5$ & 6 & 7 & 12 & 29.0 & 36.7 \\
\hline HSW-69 & $7-9.5$ & 3 & 3 & 7 & 2.9 & 4.1 \\
\hline
\end{tabular}

${ }^{1}$ Olney

${ }^{2}$ The grain size where 10 percent of the sample is finer than the effective grain size and 90 percent is coarser than the effective grain size.

${ }^{3}$ The grain size where 25 percent of the sample is finer than the effective grain size and 75 percent is coarser than theeffective grain size.

\section{Relation Between Hydraulic Conductivity and Ground-Penetrating-Radar Data}

Commonly identified GPR reflector signatures were qualitatively correlated with hydraulic properties estimated from the grain-size analysis and single-well aquifer tests. This correlation allows extrapolation of point-hydraulic data to places in the aquifer where well or boring data are unavailable; thus, horizontal and vertical distributions of hydraulic data can be generated.

Part of GPR profile B - B' and nested well pair HSW-51 and HSW-64 are shown in figure 8. The horizontal hydraulic conductivity for the screened interval shown on figure 8 can be quantitatively associated with the reflector signature indicated on the profile. This association is then applied to the entire GPR section. The screen of well HSW-64 is open to the steeply dipping, parallel to hummocky reflectors (fig. 8); these reflectors were determined to be representative of mostly medium sand, and the corresponding calculated horizontal hydraulic conductivity is $64 \mathrm{ft} / \mathrm{d}$. The hydraulic-conductivity estimates at well HSW-64 ranged from 25 to $39 \mathrm{ft} / \mathrm{d}$ from bulk methods, and 64 to $80 \mathrm{ft} / \mathrm{d}$ (table 4) from single-well aquifer tests.

The screen of well HSW-51 is open to aquifer materials that show as strong, flat-lying, parallel 


\section{Portion of Ground-Penetrating-Radar profile B}

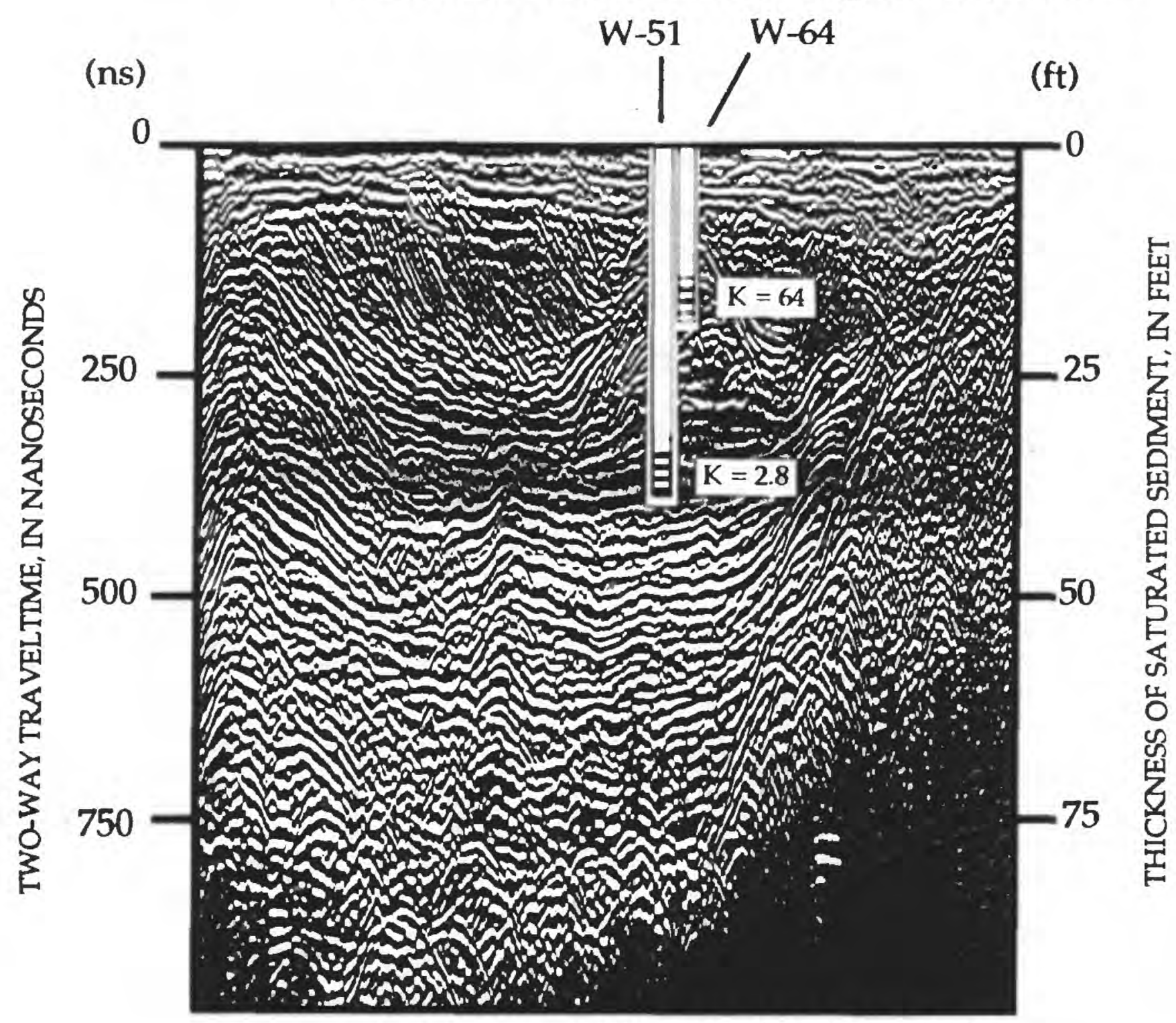

VERTICAL EXAGGERATION X 3

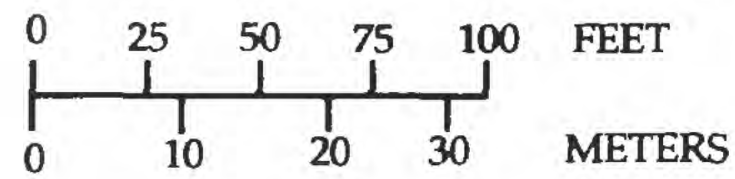

APPROXIMATE HORIZONTAL DISTANCE

\section{EXPLANATION}

$\left\{\begin{array}{l}\text { Well casing } \\ \text { Well screen }\end{array}\right.$

$\mathrm{K}=$ HYDRUALIC CONDUCTIVITY-In feet per day determined by methods from Bouwer and Rice (1976).

Figure 8. Relation between horizontal hydraulic conductivity and ground-penetrating-radar reflector signature for part of profile B-B' near northern end of Flints Pond. Hollis, New Hampshire. 
reflectors that indicate the presence of very fine grained sands and silt. The hydraulic conductivity, calculated from methods developed by Bouwer and Rice (1976), is $2.8 \mathrm{ft} / \mathrm{d}$; the range of estimates is 2.8 to $12 \mathrm{ft} / \mathrm{d}$.

The hydraulic data and associated GPR-reflector signature from one GPR profile can be extrapolated to other profiles in the aquifer. This process, however, depends on the availability of wells and aquifer-test results in the various reflector types to establish a relation between the hydraulic data and the GPR reflectors. Testing of additional wells in aquifer materials with similar reflector signatures can improve the reliability of the technique.

\section{SUMMARY AND CONCLUSIONS}

Flints Pond has been subjected to accelerated eutrophication as a result of watershed development (building of new homes and conversion of summer cottages into permanent homes) since the 1930's. Ground water is the primary source of water for recharge to the 50 -acre Flints Pond. The aquifer in the Flints Pond area is comprised of glaciofluvial and glaciolacustrine sands and gravels that are related to the various stages of the glacial lake that once occupied the area. Information on the geohydrology of the adjacent Flints Pond aquifer can be used in developing a water and nutrient budget for the pond-aquifer system, which could be used to design a remediation plan to improve the water quality of the pond. A detailed water-table map and an aquifer saturated-thickness and transmissivity map were produced. The saturated thickness and transmissivity of the aquifer and altitude of the water table were determined by use of GPR, test-drilling, and aquifer-test data.

GPR surveys were done over more than $4 \mathrm{mi}$ of the study area and on Flints Pond. Three distinct reflection signatures were commonly identifiable on the radar profiles: (1) thin, relatively flat-lying, continuous reflectors, which represent fine-grained lacustrine sediment draped over the underlying till or bedrock topography or overlying coarse-grained sediment; (2) subparallel to hummocky and chaotic, coarse-grained reflectors, steeply dipping in places, which can represent coarse-grained ice-contact deposits such as eskers or crevasse fillings or can represent predominantly medium- to coarse-grained sands deposited as deltaic sediments in a lacustrine environment; and (3) sharply diffracted, fine-grained, chaotic reflectors, which represent till and (or) till over bedrock.

Actual depths to stratigraphic units determined by test drilling were correlated to the GPR data so that GPR propagation velocities could be calculated. The average velocity for saturated sediment was $0.2 \mathrm{ft} / \mathrm{ns}$ and range of velocities was from 0.18 to $0.21 \mathrm{ft} / \mathrm{ns}$.

The GPR data were used to determine the saturated thickness of the aquifer and, together with the test-drilling data, construct a saturated-thickness map of the area. The saturated thickness of the aquifer exceeded $90 \mathrm{ft}$ in the northern part of the study area and averaged 30 to $50 \mathrm{ft}$ in the south and east parts of the area. The saturated thickness of the western part of the area was generally less than $10 \mathrm{ft}$.

Test borings were made at 19 locations around the pond. Seven single wells and six nested-well pairs were installed in various lithologic units. Logs were completed at each boring site, and split-spoon sediment samples were collected at 5-ft intervals. These sediment samples were analyzed for grain-size distribution, and the distribution data were used to calculate hydraulic conductivities for various lithologies.

Water-level measurements were made monthly from April 1993 through November 1994. Water fluctuations over the period measured ranged from $0.67 \mathrm{ft}$ in the middle of the aquifer to more than $5 \mathrm{ft}$ toward the edges of the aquifer. A water-table map was constructed from data collected in November 1994 and is considered to represent average ground-water levels in the aquifer.

Single-well aquifer tests were done at selected wells to determine horizontal hydraulic conductivity. These test results compared favorably with the results determined from grain-size analyses. Horizontal hydraulic conductivities calculated by the Bouwer and Rice (1976) method for stratified drift range from 2.0 to $226 \mathrm{ft} / \mathrm{d}$. Horizontal hydraulic conductivities are greatest at the south and west ends of the pond.

Hydraulic conductivities were quantitatively correlated to the reflector signatures identified with GPR. As a result of the correlation, transmissivities 
were extrapolated for areas where well data were unavailable but where GPR surveys were done. An aquifer saturated-thickness and transmissivity map for the study area indicates that transmissivities exceed $3,000 \mathrm{ft}^{2} / \mathrm{d}$ in the southern and east-central part of the aquifer. In the northern part, transmissivity ranges from 1,000 to $2,000 \mathrm{ft}^{2} / \mathrm{d}$. Transmissivity is generally less than $1,000 \mathrm{ft}^{2} / \mathrm{d}$ in the western part of the aquifer.

\section{SELECTED REFERENCES}

Ayotte, J.D., 1994, Use of ground-penetrating radar to determine the depositional environment of glacial deposits in southern New Hampshire in Bell, R.S., and Lepper, C.M., eds., Proceedings of the Application of Geophysics to Engineering and Environmental Problems Symposium, March 27-31, 1994, Boston, Massachusetts: Environmental and Engineering Geophysical Society, v. 2., p. 629-643.

Ayotte, J.D., and Dorgan, T.H., 1995, Results of geophysical surveys of glacial deposits near a former waste-disposal site, Nashua, New Hampshire: U.S. Geological Survey Open-File Report 95-142.

Ayotte J.D., and Toppin, K.W., 1995, Geohydrology and water quality of stratified-drift aquifers in the middle Merrimack River Basin, south-central New Hampshire: U.S. Geological Survey Water-Resources Investigations Report 92-4192, 52 p., 8 pls.

Barr, G.L., 1993, Application of ground-penetrating radar methods in determining the hydrogeologic conditions in a karst area, west-central Florida: U.S. Geological Survey Water-Resources Investigations Report 92-4141, $26 \mathrm{p}$.

Bedinger, M.S., 1961, Relation between median grain size and permeability in the Arkansas River Valley, Arkansas in Geological Survey Research, 1961, Short papers in the geologic and hydrologic sciences, articles 147-292: U.S. Geological Survey Professional Paper 424-C, p. C31-C32.

Beres, Milan, Jr., and Haeni, F.P., 1991, Application of ground-penetrating-radar methods in hydrogeologic studies: Ground Water, v. 29, no. 3, p. 375-386.

Bouwer, Herman, and Rice, R.C., 1976, A slug test for determining hydraulic conductivity of unconfined aquifers with completely or partially penetrating wells: Water-Resources Research, v. 12, no. 3, p. 423-428.
Cotton, J.E., 1977, Availability of ground water in the lower Merrimack River Basin, southern New Hampshire: U.S. Geological Survey Water-Resources Investigations $77-69$, scale 1:125,000.

Folk, R.L., 1974, Petrology of sedimentary rocks: Austin, Tex., Hemphill Publishing Co., 182 p.

Geophysical Survey Systems, Inc., 1974, Continuous subsurface profiling by impulse radar: Hudson, N.H., Geophysical Survey Systems, Inc., 20 p.

Haeni, F.P., 1992, Use of ground-penetrating radar and continuous seismic-reflection profiling on surface-water bodies in environmental and engineering studies in Bell, R.S. (ed.), Procedings of the Application of Geophysics to Engineering and Environmental Problems Symposium, April 26-29, 1992, Oak Brook, Illinois: Golden, Colo., Society of Engineering and Mineral Exploration Geophysicists, p. 145-162.

Haeni, F.P., McKeegan, D.K., and Capron, D.R., 1987, Ground-penetrating radar study of the thickness and extent of sediments beneath Silver Lake, Berlin, and Meriden, Connecticut: U.S. Geological Survey Water-Resources Investigations Report 85-4108, $19 \mathrm{p}$.

Hansen, B.P., 1993, Results of geophysical surveys at Hocomonco Pond, Westborough, Massachusetts: U.S. Geological Survey Open-File Report 92-646, 19 p.

Hvorslev, M.J., 1951, Time lag and soil permeability in groundwater observations: Vicksburg, Miss., U.S. Army Corps of Engineers Waterway Experimental Station Bulletin $36,49 \mathrm{p}$.

Johnson, D.G., 1992, Use of ground-penetrating radar for water-table mapping, Brewster and Harwich, Massachusetts: U.S. Geological Survey Water-Resources Investigations Report 90-4086, $27 \mathrm{p}$.

Koteff, Carl, 1970, Surficial geologic map of the Milford Quadrangle, Hillsborough County, New Hampshire: U.S. Geological Survey Geologic Quadrangle Map GQ-881, scale 1:62,500.

Koteff, Carl, 1976, Surficial geologic map of the Nashua North Quadrangle, Hillsborough and Rockingham Counties, New Hampshire: U.S. Geological Survey Geologic Quadrangle Map GQ-1290, scale 1:24,000.

Koteff, Carl, and Volckmann, R.P., 1973, Surficial geologic map of the Pepperell Quadrangle, Middlesex County, Massachusetts, and Hillsborough County, New Hampshire: U.S. Geological Survey Geologic Quadrangle Map GQ-1118, scale 1:24,000. 
Krumbein, W.C., and Monk, G.D., 1942, Permeability as a function of the size parameters of unconsolidated sand: Transactions of the American Institute of Mineralogical and Metallurgical Engineers, v. 151, p. 153-163.

Lyons, J.B., Bothner, W.A., Moench, R.H., and Thompson, J.B.,Jr., eds., 1986, Interim geologic map of New Hampshire: New Hampshire Department of Resources and Economic Development, Open-File Report 86-1, scale 1:250,000.

Lohman, S.W, and others, 1972, Definitions of selected ground-water terms - revisions and conceptual refinements: U.S. Geological Survey Water-Supply Paper 1988, $21 \mathrm{p}$.

Masch F.D., and Denny, K.J., 1966, Grain size distribution and its effect on the permeability of unconsolidated sands: Water Resources Research, v. 2, no. 4, p. 665-677.

Moore, R.B., 1990, Geohydrology and water quality of stratified-drift aquifers in the Exeter, Lamprey, and Oyster River Basins, southeastern New Hampshire: U.S. Geological Survey Water-Resources Investigations Report 88-4128, 61 p., 8 pls.

Olney, S.L., 1983, An investigation of the relationship between the coefficient of permeability and effective grain size of unconsolidated sands: Boston, Mass., Boston University, unpublished Master's thesis, $61 \mathrm{p}$.

Todd, D.K., 1980, Groundwater hydrology (2d ed.): New York, John Wiley and Sons, $535 \mathrm{p}$.

Toppin, K.W., 1987, Hydrogeology of stratified-drift aquifers and water quality in the Nashua Regional Planning Commission Area, south-central New Hampshire: U.S. Geological Survey Water-Resources Investigations Report 86-4358, $101 \mathrm{p}$. 